\title{
STUDNIA - SZCZEGÓLNY OBIEKT W PRZESTRZENI STANOWISKA ARCHEOLOGICZNEGO. WPROWADZENIE DO PROBLEMATYKI BADAWCZEJ ${ }^{1}$
}

\author{
WELL - A SPECIAL OBJECT IN THE AREA \\ OF THE ARCHAEOLOGICAL SITE. \\ INTRODUCTION TO THE RESEARCH PROBLEM
}

\author{
Magdalena Piotrowska \\ Instytut Archeologii, Uniwersytet Adama Mickiewicza \\ ul. Umultowska 89D, 61-614 Poznań \\ piotrowskamagda@op.pl; magpio2@amu.edu.pl \\ Andrzej Michałowski \\ Instytut Archeologii, Uniwersytet Adama Mickiewicza \\ ul. Umultowska 89D, 61-614 Poznań \\ andrzej.michalowski@amu.edu.pl
}

\begin{abstract}
A significant increase in the amount of materials obtained from the recent large area excavations resulted in numerous finds of wells. For years, these unique archaeological features were not treated as a separate research problem. In order to obtain the fullest research results, an increasing interdisciplinarity involving different fields of science is applied to the studies on wells nowadays. Constructions made of organic raw materials are extremely rare in the space of a typical archaeological site and they are also extremely important sources for gaining knowledge about particular settlements. Wells are accompanied by a certain range of features related to the use of water intake and located in its immediate vicinity. These discoveries allow for extremely interesting interpretations of the functional connections between individual complexes of this type. Functions of wells are an issue
\end{abstract}

\footnotetext{
${ }^{1}$ Temat realizowany w ramach projektu badawczego/stażu po uzyskaniu stopnia naukowego doktora o $\mathrm{nr}$ 2015/16/S/HS3/00241 finansowanego ze środków Narodowego Centrum Nauki.
} 
that is inextricably linked to the location of such complexes in the settlement's space. Another aspect related to studies of these features is their extremely rich symbolism. Wells are special archaeological features. Their uniqueness places them among the most interesting objects studied by archaeologists.

KEY WORDS: wells, settlement, water, archaeological features, Przeworsk culture

Znaczny przyrost materiałów wynikający z prowadzonych w ostatnich latach badań szerokopłaszczyznowych dostarczył licznych odkryć studni. Studia nad tymi szczególnymi obiektami archeologicznymi, jako oddzielny problem badawczy, od lat nie były podejmowane. Do czasu rozwoju badań ratowniczych i szerokopłaszczyznowch w ramach wielkich inwestycji studnie należały do źródeł stosunkowo rzadko rejestrowanych $\mathrm{w}$ trakcie badań archeologicznych oraz do obiektów, które w przeciwieństwie np. do grobów nie były odkryciami przypadkowymi ze względu na swoje znaczne zagłębienie w podłoże, co z drugiej strony chroniło te obiekty - pozostałości ich drewnianych konstrukcji - przed destrukcją (Piotrowska, 2017). W związku ze znacznym przyrostem materiałów zmieniły się także sposoby postrzegania oraz analizy tych nieruchomych źródeł. W badaniach nad studniami zauważalna jest coraz większa interdyscyplinarność - angażowanie różnych dziedzin nauki w celu uzyskania jak najpełniejszych wyników badań. Szczególnego znaczenia nabiera głównie współpraca z różnymi naukami przyrodniczymi. Obok tych środowiskowych pod uwagę brane są także uwarunkowania społeczne oraz kulturowe, co czyni te obiekty tym bardziej ważnymi w badaniach pradziejów. Badania paleoekologiczne, takie jak analiza palinologiczna makroszczątków czy antrakologiczna oraz np. pokazanie uziarnienia osadów ze studni pozwalają m.in. na rekonstrukcję dawnego krajobrazu i określenie zmian warunków środowiska, jakie zachodziły w czasie wypełniania się studni oraz w jej najbliższym otoczeniu. Oszacowanie stopnia przydatności wód do spożycia, czyli ich jakości, możliwe jest dzięki analizom geochemicznym. Z podłożem kulturowym oraz społecznym może mieć natomiast związek sposobu budowy danego rodzaju ujęcia wody w obrębie stanowiska, jego miejsce w przestrzeni osady oraz pełnione funkcje, np. kultowe.

Niniejszy artykuł ma na celu ponowną prezentację tych źródeł nieruchomych na wybranych przykładach jako niezmiernie interesujących obiektów archeologicznych. Ma on także w założeniu pozwolić na wprowadzenie czytelnika w metodykę ich badań. Tekst ten nie wyczerpuje rzecz jasna tego bardzo obszernego tematu, a jedynie wprowadza w problematykę znaczenia pradziejowych sztucznych ujęć wody w przestrzeni stanowiska archeologicznego.

Inspiracją do podjęcia tytułowego zagadnienia było odkrycie ponad stu tego typu obiektów na stanowisku w Kwiatkowie, gm. Brudzew, pow. turecki, z których 
zdecydowana większość jest wiązana z okresem wpływów rzymskich. $Z$ tego też względu prowadzona analiza będzie się opierać w znacznej mierze na znaleziskach z tego właśnie okresu.

\section{WPROWADZENIE DO PROBLEMATYKI „STUDZIENNEJ” - CHARAKTER ŹRÓDEL I STAN BADAŃ}

Studnie to szczególne obiekty archeologiczne. Konstrukcje wykonane z surowców organicznych zachowują się niezmiernie rzadko w przestrzeni typowego stanowiska archeologicznego, w przypadku studni mamy natomiast bardzo często do czynienia z zachowaniem ich elementów organicznych. Są to zazwyczaj dolne partie drewnianych cembrowin. Rejestrowane są one wszędzie tam, gdzie poziom wód gruntowych był na tyle wysoki, aby przy dużym stopniu wilgotności i ograniczonym dostępie tlenu mogły się zachować (Lityńska-Zając, Wasylikowa, 2005). Drewniane elementy cembrowin są niezwykle ważnymi źródłami do uściślenia datowania stanowiska, w którego przestrzeni funkcjonują obiekty studzienne. Pozwalają one na wykonanie badań dendrochronologicznych i porównanie ich ustaleń z datowaniem zabytków wydobytych $\mathrm{z}$ ich wypełnisk. Konstrukcje zastosowane przy wznoszeniu cembrowin stwarzają możliwość oceny umiejętności ciesielskich ówczesnych budowniczych. Dodatkowo większość z tych obiektów miała zapewne także konstrukcję naziemną. Poszukiwanie i analiza ich pozostałości - obudowy otworu studziennego lub innych obiektów towarzyszących w postaci np. zadaszenia nad studnią czy urządzeń służących do czerpania wody sprawia, że są to źródła o niezwykłym ładunku wiedzy o przeszłości.

Liczba odkrywanych osad nie idzie w parze $\mathrm{z}$ liczbą rejestrowanych studni, co jest związane jedynie $z$ fragmentarycznym rozpoznaniem stanowisk. Mimo szerokopłaszczyznowych prac badawczych, większość działań ratowniczych poprzedzających budowę przede wszystkim założeń liniowych charakteryzuje się ograniczeniem badanego terenu do pasa technologicznego takiej inwestycji. Brak studni w obrębie wykopu może wiązać się z tym, że mogły się one znajdować poza nim albo w jego bezpośrednim sąsiedztwie. Tym samym wnioski wysuwane na podstawie dostępnego do prac badawczych fragmentu terenu mogą odbiegać w rezultacie od rzeczywistości.

W ostatnich latach szczególnie liczba sztucznych ujęć wody znanych z osad kultury przeworskiej istotnie się zwiększyła. Wiąże się to ze wspomnianymi ratowniczymi badaniami prowadzonymi na szeroką skalę oraz z tym, że od czasów funkcjonowania tej kultury obiekty te zyskały na znaczeniu i zaczęto częściej kopać sztuczne ujęcia wody w porównaniu z wcześniejszymi odcinkami pradziejów.

Kolejne ograniczenia w dostępie do interesujących nas obiektów wynikają ze sposobu opracowywania badań wykopaliskowych oraz ich publikacji. Przyrost bazy 
materiałowej niestety nie ma odzwierciedlenia w liczbie publikowanych opracowań, gdzie wśród innych obiektów omawiane są również studnie (zob. m.in. Jurkiewicz, Machajewski, 2006, s. 144-146; Piotrowska, 2016, s. 63-95; Piotrowska, 2017). Wzmianki na temat tego rodzaju obiektów są dość liczne, ale głównie ograniczają się tylko do krótkich komunikatów na ich temat, najczęściej przy okazji publikacji wstępnych wyników badań, na których często kończy się informacja o badanych stanowiskach. Warto nadmienić, że studnie z okresu wpływów rzymskich były również tematem niepublikowanych prac magisterskich, które niestety nie wyczerpały tematu, a jedynie ogólnie zasygnalizowały pewne aspekty (Zawisza, 1983; Bączyński, 2000; zob. Piotrowska, 2017). W większości opracowań naukowych, gdzie znajdują się informacje o studniach, ograniczają się one jedynie do podania wymiarów obiektów oraz konstrukcji w przypadku zachowanych cembrowin. Niezmiernie rzadko można znaleźć dane dotyczące funkcji tych obiektów lub też końca ich użytkowania: czy zostały porzucone, czy wtórnie funkcjonowały jako jamy śmietniskowe, czy też zostały celowo zasypane. To samo dotyczy pochodzących ze studni zabytków. Ich lokalizacja w obrębie wypełniska, stan zachowania - stopień zniszczenia, wielkość nie są często satysfakcjonująco opisane przy omawianiu studni. Podobnie w przypadku ewentualnych napraw, czyszczenia lub rozbierania górnych partii cembrowin w celu wtórnego użycia budulca. Fragmentaryczne rozpoznanie przestrzeni reliktowych nie pozwala też często na pewne określenie miejsca studni w obrębie osady. Warto zauważyć, że stan badań nad studniami na zachód od ziem polskich w pierwszych wiekach naszej ery prezentuje się niewiele lepiej (m.in. Gaude, 1995; Schöneburg, 1996; Biermann, 2001; Schmidt, 2003; Leube, 2009; Greif, 2015).

\section{STUDNIA - DEFINICJA I HISTORIA}

Studnia, jak definiuje „Słownik języka polskiego”, to pionowe (czasami skośne) ujęcie wód podziemnych, sztuczny otwór wiercony lub kopany, sięgający do poziomu wodonośnego (https://sjp.pwn.pl/szukaj/studnia.html). W przypadku pradziejów mamy do czynienia ze sztucznym ujęciem wody kopanym, czyli szybowym. $Z$ reguły charakteryzował się on obecnością obudowy, którą stanowiła cembrowina.

Samo określenie studnia (stud - zimno, studzić) w wielu językach pochodzi od „,zimnej wody” (Brückner, 1927) lub ciepłych źródeł, które po wypłynięciu na powierzchnię ulegają właśnie ostudzeniu (Grimm, Grimm, 1860). Zagadnienie pochodzenia tego słowa zwłaszcza $w$ językach germańskich znalazło swoje miejsce w Reallexikon der germanischen Altertumskunde (Beck, 1918/1919). Zarówno obszerniejsze i interesujące wyjaśnienia etymologiczne, jak i znaczenia symbolicznego słowa studnia znajdujemy m.in. w publikacji dotyczącej motywu studni w literaturze i sztuce niemieckiej (Wolting, 2005, s. 18, 19). 
Alternatywne określenia dla studni to źródło, zdrój, krynica. Ma to związek z naturalnie wybijającymi na powierzchnię wodami, których ujęcia często obudowywano - wznoszono zarówno konstrukcje drewniane, jak i kamienne. Synonimem jest także słowo fontanna pochodzące od łacińskiego słowa fons, oznaczającego zarówno naturalne źródło, jak i ujęcie sztuczne - konstrukcję dostarczającą wodę, nierzadko mającą znaczenie również symboliczne (Juuti i in., 2015, s. 2315). Problemem jest kwestia zabezpieczania obudowy takich miejsc, ponieważ ze względu na usytuowanie na powierzchni łatwiej ulegały destrukcji niż konstrukcje zagłębione w podłoże. Poświadczone wykorzystanie takich źródeł znane jest od młodszej epoki kamienia (zob. Elburg, 2011; Juuti i in., 2015). Do dziś źródełka cieszą się wielkim powodzeniem, często ze względu na lecznicze walory wybijającej wody.

Same studnie, te sięgające podziemnych warstw wodonośnych, do niedawna były jeszcze nieodzownym elementem krajobrazu wiejskiego (ryc. 1). Znajdowały się w obrębie poszczególnych zagród - gospodarstw w centrum wsi bądź osady lub już poza jej granicami. Podobnie ma się rzecz, jeśli chodzi o miejsce studni w kontekście stanowisk archeologicznych (por. Piotrowska, 2018). Studnie to mało zmienne w czasie obiekty archeologiczne, te najstarsze, wiązane z epoką neolitu, mają analo-

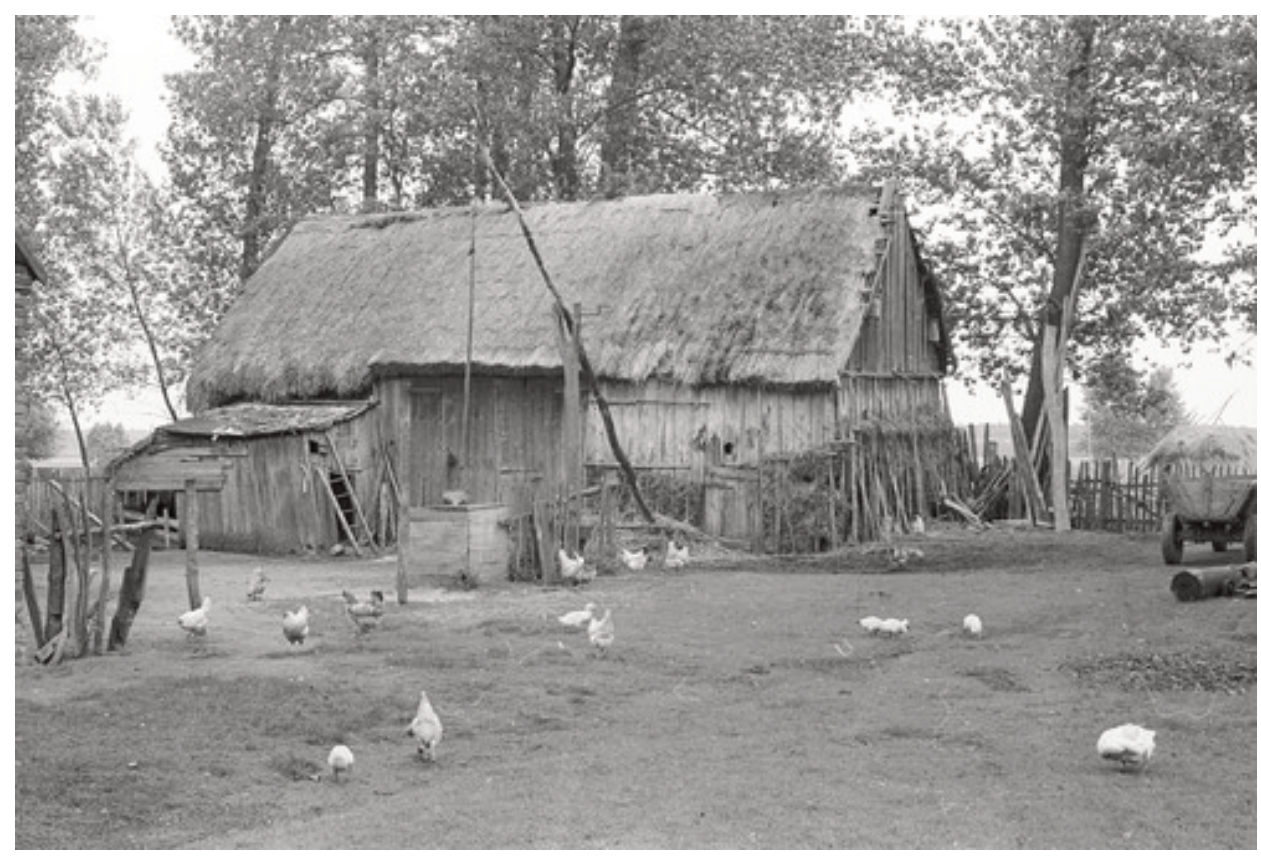

Ryc. 1. Studnia z żurawiem - lata 70. XX wieku (fot. B. Linette, Cyfrowe archiwum im. J. Burszty, $\mathrm{Nr}$ inwent.: 000547n) (http://cyfrowearchiwum.amu.edu.pl/archive?tags=studnia,\%20\&type=\&page=1).

Fig. 1. Well with the shadoof -1970 s (photo by Linette, Cyfrowe archiwum im. J. Burszty, invent. no.: 000547n) (http://cyfrowearchiwum.amu.edu.pl/archive?tags=studnia,\%20\&type=\&page=1). 
giczne konstrukcje jak te odkrywane w pierwszych wiekach naszej ery czy w czasach średniowiecza. Cembrowiny nie różnią się bardzo konstrukcyjnie od siebie, jeśli chodzi o czas ich funkcjonowania oraz szerokość geograficzną. Oczywiście istnieją różnice wiązane ze szczegółami konstrukcyjnymi oraz najczęściej z dostępnością budulca - w strefach o klimacie gorącym dominują te o cembrowinach kamiennych, zaś w klimacie umiarkowanym wykorzystywano na szeroką skalę drewno.

Od kiedy zaczęto kopać studnie? Dostęp do czystej i zdatnej do spożycia wody to podstawa funkcjonowania ludzkiego organizmu. W starożytności osadnictwo uwarunkowane było m.in. dostępem zarówno do wód płynących, jak i do wód podziemnych. Z tego powodu nie dziwi lokalizacja osad w sąsiedztwie rzek czy jezior. Tam, gdzie nie było rzek, jezior lub gdy dostęp do nich był utrudniony, pojawiała się potrzeba wykopania studni.

Pojawienie się studni wiąże się z zakładaniem pierwszych stabilnych osad w okresie neolitu. Pierwsze studnie mogły być drążone w skałach. Z tej epoki pochodzą właśnie najstarsze znane do tej pory odkrycia studni z terenów Europy (por. Minichreiter, 1998; Galili, Sharvit, 1998; Tegel, Elburg, Hakelberg, Stäuble, Büntgen, 2012). Ten ,nowy” typ obiektów archeologicznych stał się m.in. przedmiotem zbiorowej, pokonferencyjnej monografii dotyczącej odkryć studni z epoki neolitu z obszaru Europy (Koschik, 1997). Młodsza epoka kamienia to czas, kiedy osiadły tryb życia oraz nowy typ zachowań gospodarczych bazowały na wykorzystaniu wody, a tym samym wymusiły konieczność dostępu do jej zasobów. Obiekty o najstarszej metryce, charakteryzujące się drewnianymi cembrowinami, łączone są z kulturą ceramiki wstęgowej rytej z terenów Niemiec - pochodzą ze stanowiska Erkelenz-Kückhoven nad Renem i datowane są na około 5 tys. lat (Weiner, Lehmann, 1998). Jedna $\mathrm{z}$ odkrytych tam studni, której cembrowina wykonana była z dębiny, miała głębokość sięgającą do 15 metrów. Z terenów Moraw i Niemiec znane są też inne odkrycia osad wiązanych z kulturą ceramiki wstęgowej rytej, na których odkryto również sztuczne ujęcia wody z zachowanymi drewnianymi konstrukcjami. Liczba tego typu obiektów wiązanych z kolei z kulturą pucharów lejkowatych w ciągu ostatnich dziesięcioleci również znacząco wzrosła (zob. m.in. Elburg, 2011).

Od czasu młodszej epoki kamienia studnie należą do źródeł rejestrowanych podczas badań archeologicznych również na terenie Polski (zob. Rzepecki, 2014 i tam dalsza literatura). Na stanowiskach z epoki brązu i wczesnej epoki żelaza należą do odkryć niezbyt licznie spotykanych. W artykule dotyczącym systematyzacji oraz interpretacji obiektów odkrywanych na terenie osad kultury łużyckiej odnajdujemy informację, że studnie to źródła nieruchome, rzadko stosowane przez ludność wspomnianej kultury. Autor wymienia zaledwie kilka takich obiektów (Michalski, 1983, s. 164). W związku z olbrzymim przyrostem materiałów od czasu tej pracy stwierdzenie to, dotyczące kultury łużyckiej, wymaga weryfikacji, ponieważ badania w związku z budową autostrad dostarczyły nowych znalezisk, jednak nie tak licznych jak z późniejszych odcinków pradziejów (por. m.in. Krzyszowski, 2012, s. 223, 226, 237, 239; Czerniak, Kabaciński, 2004, s. 152, 153). 
Nieporównywalnie więcej studni znanych było i jest ze stanowisk wiązanych z kulturą przeworską (por. Nowakowski, Waluś, 1980; Piotrowska, 2017). Badania szerokopłaszczyznowe z ostatnich lat dostarczyły bardzo licznych źródeł z okresu przedrzymskiego oraz wpływów rzymskich, a co za tym idzie także odkryć sztucznych ujęć wody. Od czasów funkcjonowania kultury przeworskiej studnie zyskały na znaczeniu i zaczęto częściej kopać ujęcia wody w porównaniu z wcześniejszymi odcinkami pradziejów. Podobnie ma się rzecz na zachód od naszych ziem, gdzie od I wieku n.e. znaczenie studni $\mathrm{w}$ zaopatrzeniu $\mathrm{w}$ wodę ludności znacznie wzrasta (Leube, 2009, s. 162). Na przestrzeni dziejów obiekty te spotykane są również na osadach zlokalizowanych w pobliżu naturalnych źródeł wody, a ich obecność w tym wypadku podyktowana była zapewne względami pragmatycznymi i chęcią posiadania studni w obrębie osady. Potrzeba budowy tych obiektów pojawiała się także w momencie, gdy istniało duże zapotrzebowanie na wodę podyktowane np. wyspecjalizowaną wytwórczością. Studnie mogą też znajdować się już poza zwartą zabudową osady, co sprawia, że mogą być trudne do uchwycenia w trakcie eksploracji terenu. Studnie położone relatywnie daleko od osad, w pewnej izolacji, są czasem trudne do wydatowania.

Informacje na temat studni odnajdywane są w przekazach starożytnych. Jak podaje Pliniusz Starszy, pierwsze studnie powstały w Egipcie. W części poświęconej wynalazkom i ich twórcom znajduje się krótki fragment traktujący o tytułowych obiektach: „Studnie (wynalazł - przyp. autora) Danaus, który przyszedł z Egiptu w okolicę Grecyi zwaną Argos Dypsyon" (Plini, ks. VII, cz. LVII; Łukaszewicz, 1845, s. 149). Głównie z terenem Egiptu wiązane są również pierwsze urządzenia służące do czerpania wody (Samuels, 2014, s. 11; Noaman, Quosy, 2017, s. 21). Warto w tym miejscu wspomnieć o najstarszych znanych studniach z Chin. Są to obiekty o drewnianych konstrukcjach, których metryka wskazuje, że powstały około 6 tys. lat temu (Jiao, 2007).

Fragmenty poświęcone studniom znalazły także swoje miejsce w pracy Witruwiusza. Autor ten sporo uwagi poświęca zasadom budowy studni oraz sposobom poszukiwania najdogodniejszego miejsca sztucznego ujęcia wody. Przytacza kilka sposobów znalezienia punktów wodonośnych w terenie (Witruwiusz, ks. VIII, s. 1) polegających na obserwacji natury oraz przeprowadzaniu „eksperymentów”. Wspomniany już Pliniusz w Historii Naturalis powtarza za Witruwiuszem wskazówki dotyczące zaopatrzenia w wodę. Uważa, że woda ze studni jest dość dobrej jakości, jeśli często jest z niej czerpana, zwraca także uwagę na konstrukcję studni i sposób przenikania do niej wody (Plini, s. 31, 23).

W traktacie o sztuce budowlanej pt. $O$ architekturze ksiag dziesięć, w t. 8 odnajdujemy informacje na temat sposobów zaopatrzenia w wodę w Rzymie. Najbardziej preferowano wodę z akweduktów, następnie studzienną, a na końcu z cystern (Witruwiusz, ks. VIII, s. 1; Baatz, 1981, s. 3). W starożytnej Grecji najbardziej ceniono 
wodę źródlaną, potem rzeczną, a na końcu studzienną, w starożytnym Rzymie bardzo ceniono także wodę deszczową (Cembrzyński, 2011, s. 19). Często studnie były budowane tam, gdzie nieczystości i odpady usuwane były do rzek.

\section{STUDNIA - ŹRÓDLO ARCHEOLOGICZNE}

Biorąc pod uwagę sposób wykonania, na stanowiskach archeologicznych odkrywa się studnie kopane - szybowe. Takie studnie funkcjonowały do XIX wieku. Ręcznie wykopane sztuczne studnie charakteryzują się zazwyczaj niezbyt imponującą głębokością. Niekiedy ze względu na poziom, na jakim znajdowały się wody gruntowe, obiekty te musiały sięgać jednak głębiej. Zazwyczaj miały drewnianą bądź kamienną obudowę zabezpieczającą przed zanieczyszczeniem i uszkodzeniem. Studnie te różniły się od siebie głębokością (warunki hydrogeologiczne), konstrukcją cembrowiny, sposobem czerpania wody. Różne było także usytuowanie tych obiektów w przestrzeni reliktowej osad. Niekiedy ich funkcja nie jest taka oczywista, jak moglibyśmy przypuszczać.

Budowa studni rozpoczynała się od wykonania wkopu pod konstrukcję zabezpieczającą szyb studzienny. Zazwyczaj wody gruntowe ujmowane były z dość płytkich warstw wodonośnych, ponieważ głębokość wkopu zależała właśnie od poziomu zalegania wód gruntowych. Ręcznie kopane studnie charakteryzują się obecnością dość dużej jamy, do której wstawiano zazwyczaj drewnianą cembrowinę. Przy głębszych wkopach rozmiar jamy mógł być większy w celu uniknięcia osuwania się ziemi. Starano się także zachować przy nieco większych głębokościach pewien kąt, pod jakim kopano jamę w celu uniknięcia osuwania się ziemi (por. Wiśniewski, 1991, s. 135). Z dużym prawdopodobieństwem stosowano również szalunek. Studnie bywały pogłębiane w związku z obniżeniem lustra wód gruntowych. Wkopy pod studnie w swoich profilach mają czasami ślady po rozbieraniu górnych partii cembrowin w celu wtórnego użycia drewna.

Jamy sięgające warstw wodonośnych, w które wstawiano cembrowiny na powierzchni, charakteryzują się zazwyczaj owalnymi bądź kolistymi kształtami, rzadziej nieregularnymi planami o dość zróżnicowanych wymiarach (ryc. 2). Ich średnice zależały od wielkości, ale i kształtu cembrowiny, najczęściej wynosiły od 2 do $3 \mathrm{~m}$. Obserwacje poczynione dla tytułowych obiektów ze stanowiska w Kwiatkowie wskazują, że wkopy pod studnie najczęściej miały średnicę około 2-2,5 m (ryc. 3). $\mathrm{Z}$ reguły studnie o cembrowinach kolistych mają mniejsze zarysy w planach płaskich od tych o czworokątnej, najczęściej zrębowej konstrukcji. Wielkość ta była związana także z możliwością swobodnego kopania - pogłębiania wkopu i zapewne tym samym wygodnego operowania łopatą przez budowniczego. W studni datowanej na koniec I wieku n.e. metodami dendrochronologicznymi z osady Genshagen w Teltow znaleziono szpadel (Wanzek, 1995, s. 101). Zabytek przypominający złamany 


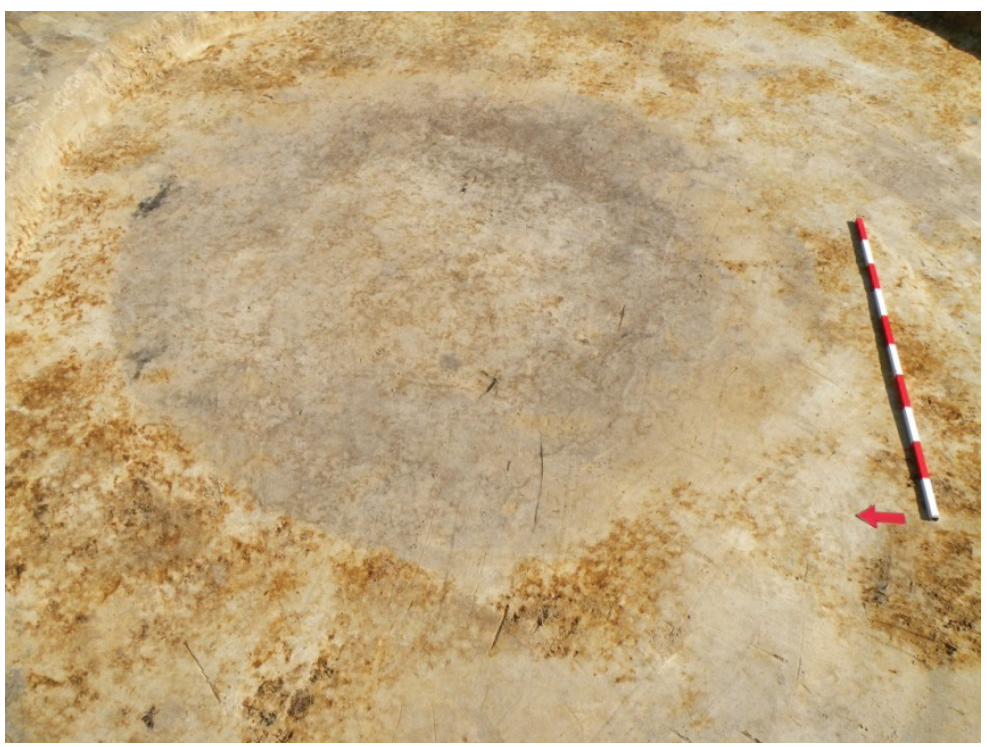

Ryc. 2. Studnia w planie płaskim przed rozpoczęciem eksploracji, stanowisko Kwiatków 11/20, gmina Brudzew (fot. E. Shellner).

Fig. 2. Pre-excavation view of the well from Kwiatków site 11/20, Brudzew commune (photo by E. Shellner).

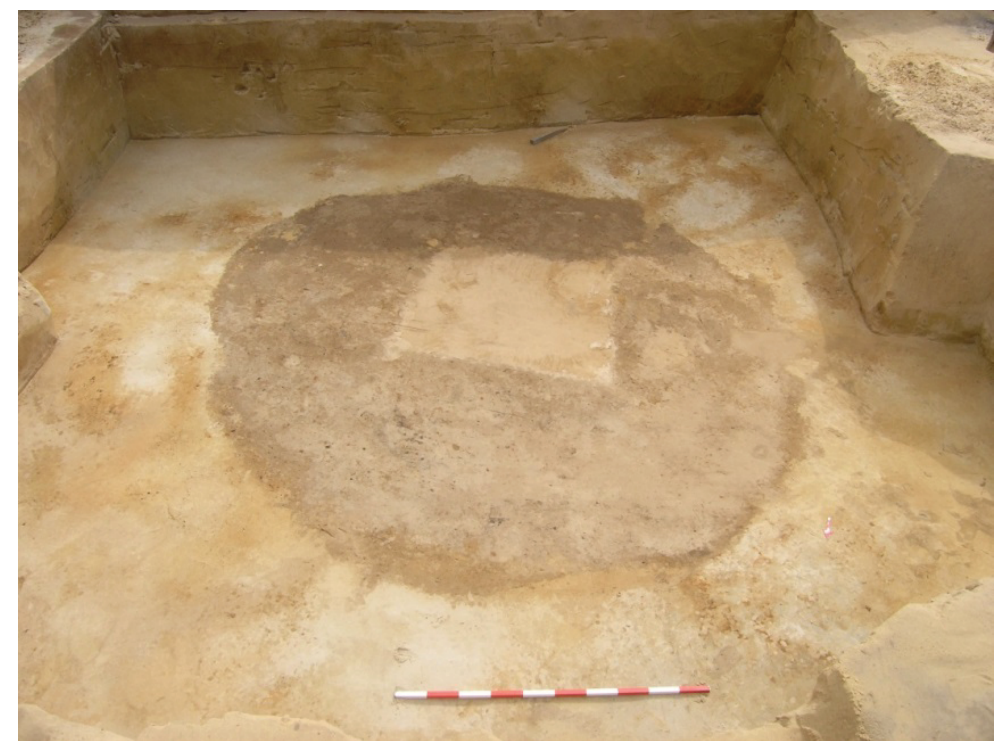

Ryc. 3. Podrys studni o cembrowinie czworokątnej w trakcie eksploracji, stanowisko Kwiatków 11/20, gmina Brudzew (fot. E. Shellner).

Fig. 3. Mid-excavation view of the well with quadrangular casing from Kwiatków site 11/20, Brudzew commune (photo by E. Shellner). 
szpadel pochodzi także z wypełniska wkopu pod studnię średniowieczną ze stanowiska Niedoradz 14, gm. Otyń (Kałagate, Jaszewska, 2005-2006, s. 446, ryc. 14). Jamy, w które wstawiano cembrowiny, miały kształty nieckowate, czworokątne lub lejowate. Wymiary wkopów pod studnie pradziejowe można zaliczyć do wąskoprzestrzennych. Znacznie większe wkopy, zwane szerokoprzestrzennymi, spotykane są w średniowieczu (Cembrzyński, 2011, s. 26). Kolejnym etapem budowy studni było umieszczenie cembrowiny w przygotowanej jamie.

\section{TYPY STUDNI - KONSTRUKCJE CEMBROWIN}

Studnie odkrywane na stanowiskach archeologicznych to oczywiście „nieczynne" już ujęcia wody. Ze względu na znaczne zagłębienie w podłoże, sięgające w większości w dalszym ciągu do warstw wodonośnych, dość dobrze zachowują się do czasów obecnych konstrukcje z surowców organicznych. Powoduje to, że w przestrzeni stanowiska archeologicznego, nawet charakteryzującego się znacznym stopniem degradacji substancji osadniczej, przedmiotowe obiekty, przy odpowiednio wysokim poziomie wód podziemnych, należą do źródeł nieruchomych relatywnie lepiej zachowanych niż inne obiekty.

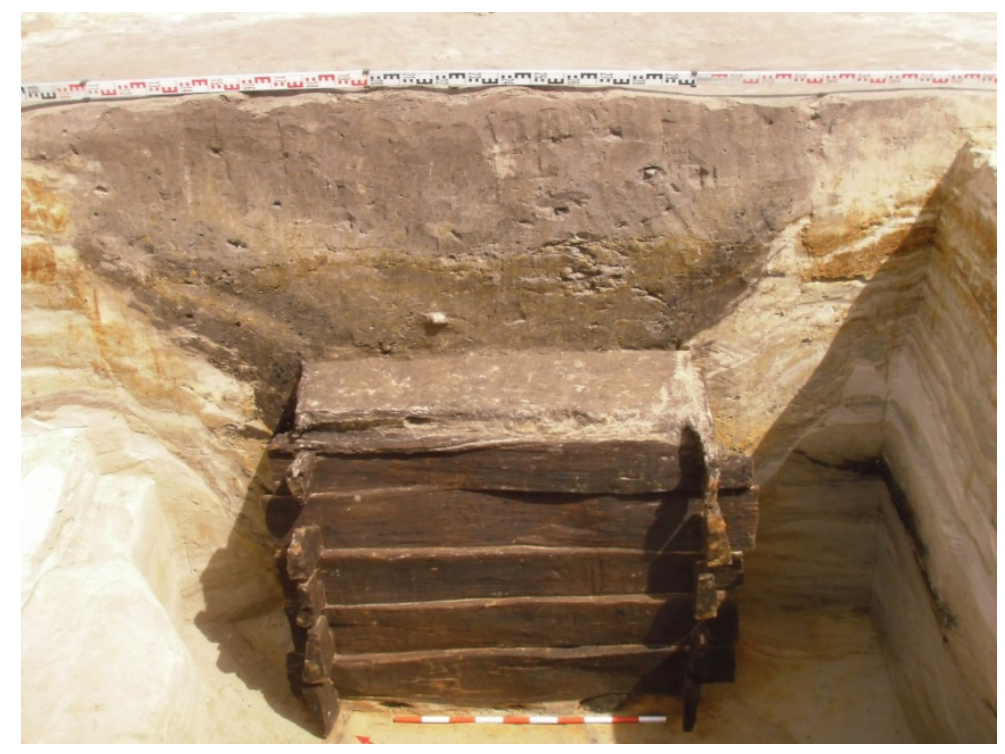

Ryc. 4. Studnia o dobrze zachowanej czworokątnej cembrowinie wzniesionej w technice zrębowej, stanowisko Kwiatków 11/20, gmina Brudzew (fot. E. Shellner).

Fig. 4. Well with the well preserved quadrangular casing built in a log construction, Kwiatków site 11/20, Brudzew commune (photo by E. Shellner). 


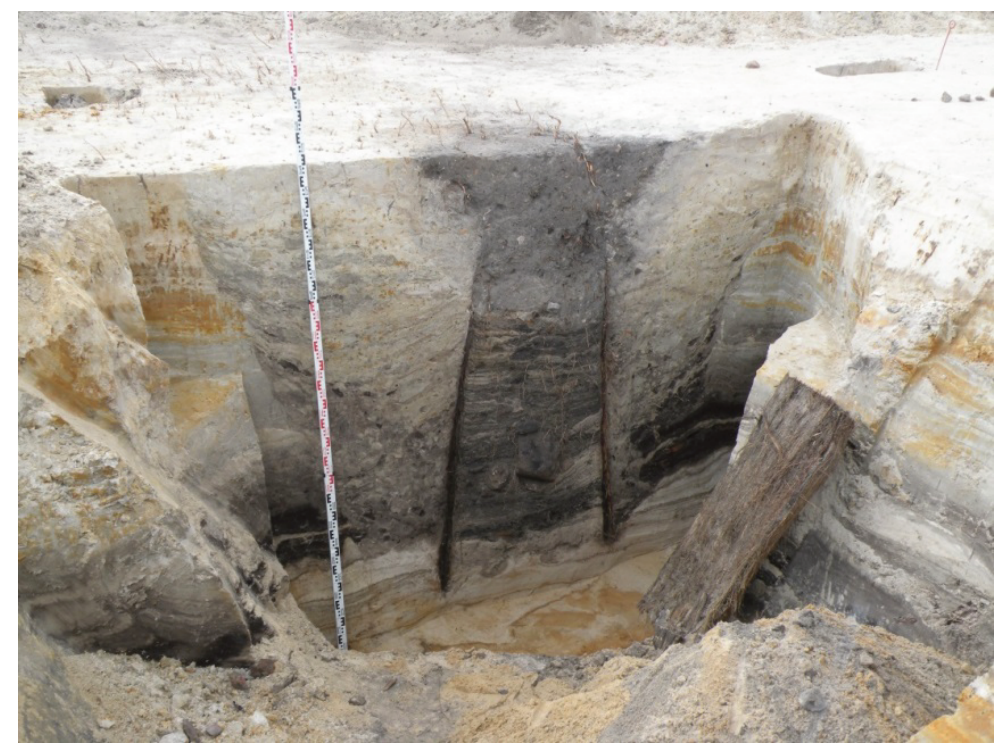

Ryc. 5. Studnia o kolistej cembrowinie wykonanej z wydrążonego pnia w trakcie eksploracji, stanowisko Kwiatków 11/20, gmina Brudzew (fot. E. Shellner).

Fig. 5. The well with round casing made of the hollowed tree trunk during the exploration, Kwiatków site 11/20, Brudzew commune (photo by E. Shellner).

Podstawą podziału studni na poszczególne typy, spotykaną w literaturze przedmiotu, są zarówno kształty cembrowin, sposoby ich konstrukcji, jak i wybór surowca, z którego budowano te obiekty. Kryterium kształtu stało się także podstawą wyróżnienia dwóch głównych grup tych obiektów w przełomowej pracy dotyczącej studni w kulturze przeworskiej. W artykule tym zastosowano podział na dwa zasadnicze typy: studnie $\mathrm{z}$ okrągłą cembrowiną i studnie z cembrowiną czworokątną (Nowakowski, Waluś, 1986, s. 44). Analogiczny podział zastosowano, omawiając studnie kultury przeworskiej ze stanowiska w Kwiatkowie. W ramach tych dwóch głównych typów wydzielono tam kolejne podtypy, uwzględniając szczegóły konstrukcyjne cembrowin, m.in. zrębowe (ryc. 4), sumikowo-łątkowe wykonane w całości z jednego pnia (ryc. 5), klepkowe czy plecionkowe (Piotrowska, 2016, s. 64). Spotykane są także obiekty charakteryzujące się obecnością podwójnej cembrowiny (ryc. 6). Podobne kryteria podziału spotykane są przy omawianiu innych stanowisk z okresu przedrzymskiego i wpływów rzymskich (por. Baron, 2014, s. 290; Jurkiewicz, Machajewski, 2006).

We wspominanej wyżej pracy dotyczącej studni z epoki neolitu (patrz: strona 142) znajdujemy przykłady podziału omawianych źródeł na te, które charakteryzują się obecnością cembrowiny (Schachtbrunnen mit Zimmerung) oraz te, bez tej konstrukcji (Schachtbrunnen ohne Zimmerung) (Weiner, 1998, s. 199). Dalsza 


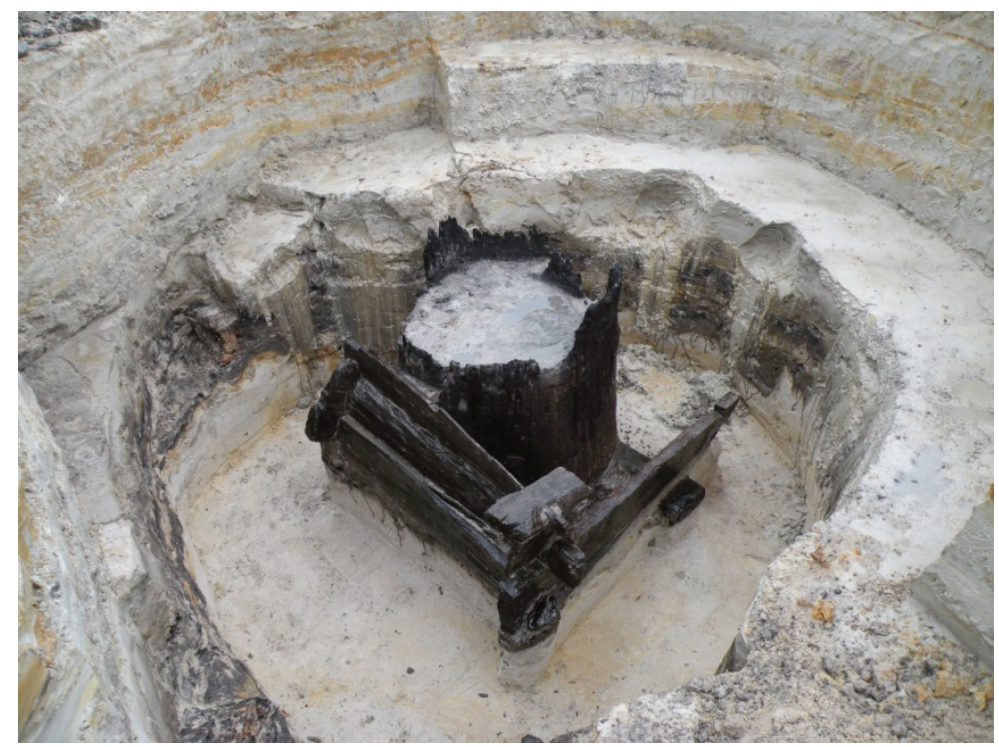

Ryc. 6. Studnia o podwójnej cembrowinie ze stanowiska Kwiatków 11/20, gmina Brudzew (fot. E. Shellner).

Fig. 6. The well with the double casing from Kwiatków site 11/20, Brudzew commune (photo by E. Shellner).

klasyfikacja w obrębie obiektów z cembrowiną dotyczy już jej kształtu, a co za tym idzie sposobu wzniesienia (Kastenbrunnen oraz Röhrenbrunnen). W literaturze obcojęzycznej funkcjonuje wiele ogólnych klasyfikacji studni, jak i tych, które tworzone były na potrzeby odkryć z poszczególnych stanowisk (Vendtova, 1966; Schöneburg, 1996; Biermann, 2001; Leube, 2009, s. 164, 165). Ze względu na pewną uniwersalność tych podziałów mogą być one stosowane dla źródeł z różnych odcinków starożytności. Przykładem może tu być zastosowanie klasyfikacji studni „słowiańskich” dla stanowiska Feddersen Wierde Kr. Cuxhaven (Haarnagel, 1979, s. 168). Podsumowanie oraz zestawienie dotyczące poszczególnych typów konstrukcji cembrowin znajduje się w pracy Studien zu Wirtschaft Und Siedlung bei den germanischen Stämmen im nördlichen Mitteleuropa während des 1. Bis 5/6. Jahrhunderts $n$. Chr (Leube, 2009, s. 161-169). Bardziej szczegółowe podziały są zawarte w pracach dyplomowych dotyczących tych obiektów z określonych obszarów i odcinków pradziejów (zob. m.in. Gaude, 1995; Schmidt, 2003; Albrecht, 2014; Greif, 2015). W przypadku studni wczesnośredniowiecznych podstawą ich podziału stały się m.in. sposoby wznoszenia cembrowin, zastosowane konstrukcje, dla których odniesieniem była praca F. Biermanna (Biermann, 2001; Cembrzyński, 2011, s. 22, 23).

Jak już wyżej pisano, kryterium podziału prezentowanych obiektów jest także surowiec-budulec, z którego została wykonana cembrowina. Na terenach ziem Polski oraz obszarach sąsiadujących w starożytności zdecydowanie dominowały ujęcia 
wody charakteryzujące się konstrukcjami wykonanymi z materiałów organicznych. Oczywiście zależało to od dostępności surowca, a co za tym idzie także warunków środowiskowych, klimatu oraz postępu technologicznego. Gatunkiem preferowanym do wznoszenia obudowy studziennej w pierwszych wiekach naszej ery był dąb (por. Nowakowski, Waluś, 1981). Większość cembrowin odkrytych na stanowisku w Kwiatkowie także została wykonana $\mathrm{z}$ tego drewna. Nie dziwi to ze względu na właściwości dębu, na które w swojej pracy zwraca uwagę wspominany już Witruwiusz. Czytamy u niego, że dąb użyty przy konstrukcjach podziemnych cechuje nieprzemijająca trwałość (Witruwiusz, II, s. 9). Przedstawiciele kultury przeworskiej, budując cembrowiny, zdawali sobie sprawę z właściwości wybranego do tego celu gatunku drewna.

W literaturze etnograficznej także spotykamy propozycje typologicznych klasyfikacji studni. Można tu wymienić klasyfikację U. Mygi-Piątek (Myga-Piątek, 2002), gdzie pod uwagę przy podziale ujęć wody brane były m.in. wiek i rodzaj utworów wodonośnych, głębokość, budowa wewnętrzna studni i jej obudowa zewnętrzna - rodzaj zabezpieczeń, wielkość wlotu studziennego, stan sanitarny.

\section{OBIEKTY „TOWARZYSZACE” STUDNIOM}

Studnie to nie tylko szyby sięgające warstw wodonośnych, to także ich konstrukcje naziemne związane $\mathrm{z}$ tymi założeniami. Towarzyszy im też pewna gama obiektów powiązanych $z$ użytkowaniem ujęcia wody, a sytuowanych w bezpośrednim jego pobliżu. Odkrycia te pozwalają na interpretację powiązań funkcjonalnych poszczególnych kompleksów tego typu. Bardzo cennymi źródłami, które pomocne są $\mathrm{w}$ tego typu analizie, stają się niewątpliwie wszelakie analogie etnograficzne, co wynika z małej zmienności charakteru rzeczonych konstrukcji na przestrzeni czasu.

Większość studni odkrywanych na stanowiskach archeologicznych miała prawdopodobnie naziemną część cembrowiny, która mogła być zaopatrzona w dodatkową przykrywę wlotu zabezpieczającą otwór studzienny i chroniąca go przed zanieczyszczeniami. Taka niezabezpieczona studnia stanowiła zagrożenie wewnątrz osady. Z drugiej strony analogie etnograficzne wskazują, że nie każda studnia musi mieć zabezpieczenie osłaniające otwór studzienny (zob. Makiewicz i in., 2008). Płytkie ręcznie kopane studnie były bardzo narażone na zanieczyszczenia pochodzące z powierzchni, jak i te przenikające do wód gruntowych. Głównym źródłem zanieczyszczenia były zwierzęce i ludzkie odchody.

Studnie wraz z urządzeniami znajdującymi się w ich pobliżu tworzą swoiste kompleksy funkcjonalne. Tym samym pewne obiekty archeologiczne, ujawniane w kontekście lokalizacji obok studni, mogą stać się łatwiej interpretowalnymi źródłami. Należą do nich w przeważającej mierze ślady po wkopywanych słupach, występujące zarówno pojedynczo, jak i w grupach (ryc. 7). Często bywają zlokalizowane np. wokół zarysu jamy studziennej. 


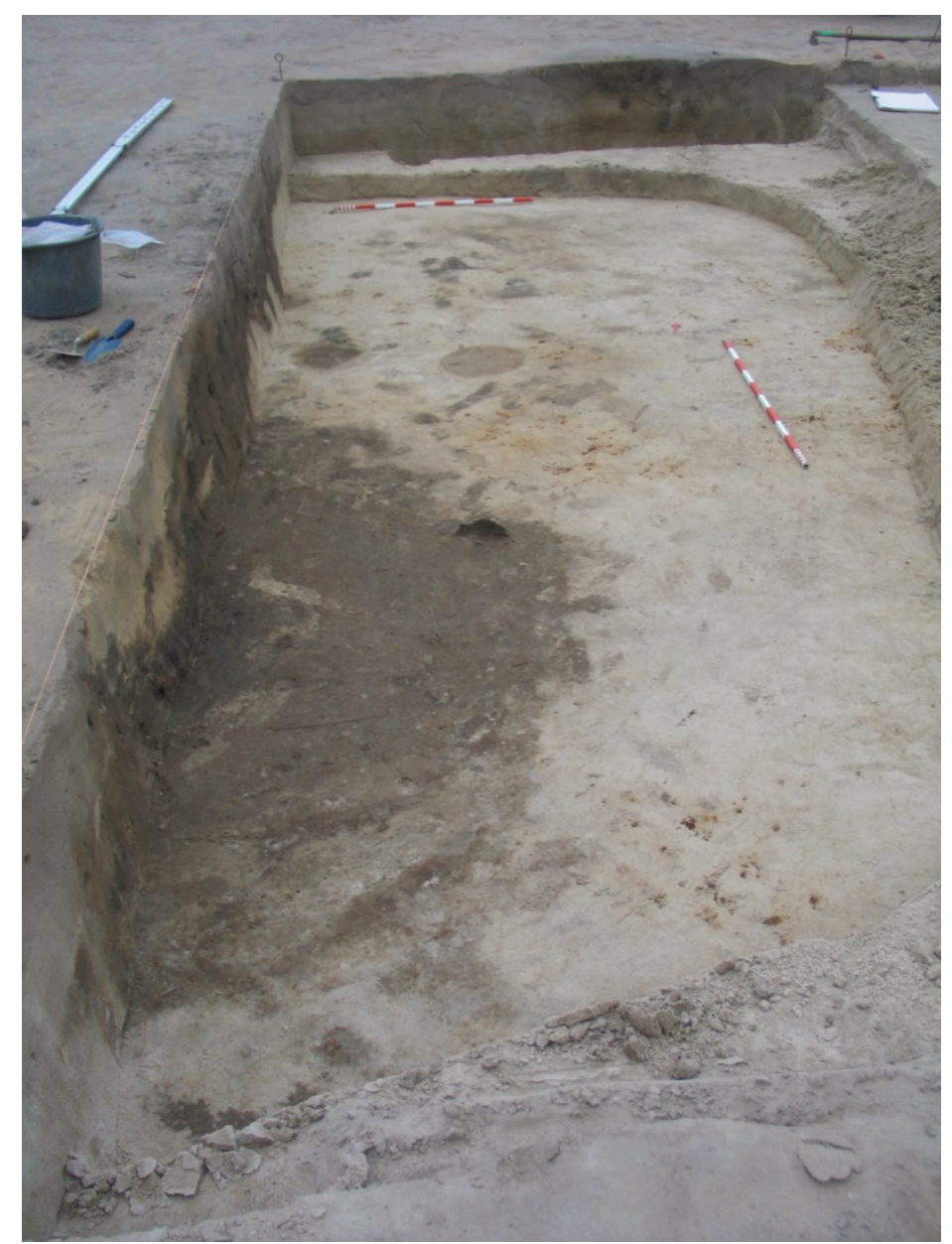

Ryc. 7. Studnia w trakcie eksploracji z widocznymi towarzyszącymi jej dołkami posłupowymi, stanowisko Kwiatków 11/20, gmina Brudzew (fot. E. Shellner).

Fig. 7. Well during the exploration and the post holes next to this feature, Kwiatków site 11/20, Brudzew commune (photo by E. Shellner).

Pojedynczy dół posłupowy posadowiony we właściwej odległości od szybu studziennego daje podstawy, aby mógł zostać zinterpretowany jako pozostałość po żurawiu służącym do poboru wody. Tego rodzaju urządzenia manifestują się z reguły w postaci pojedynczej jamy charakteryzującej się najczęściej znacznymi rozmiarami. Przy pomocy posadawianego weń żurawia czerpano wodę na terenach o stosunkowo płytkich źródłach (zob. Piotrowska, 2018).

Grupy jam posłupowych rozmieszczone wokół zarysu stropu szybu studni to prawdopodobnie ślady jakiegoś rodzaju zadaszenia lub elementu zabezpieczającego wlot otworu studziennego - rodzaj ogrodzenia/płotu (ryc. 8). Z kolei pary dołków po 
obu jej stronach zarysu cembrowiny mogły stanowić ślady po wkopanych w ziemię drewnianych słupach, na których był zamocowany kołowrót lub belka, przez którą przerzucano sznur do wyciągania naczynia z wodą (por. Piotrowska, 2018a). W późniejszym czasie zaczęto stosować częściowe zabezpieczenie tego rodzaju kołowrotu przez nakrycie go stałym daszkiem, a także całkowite zabezpieczenie przestrzeni, w której znajdowała się studnia, przez dodanie doń drewnianej osłony z zamykanymi drzwiczkami. Tego rodzaju elementy mogły mieć oprócz charakteru stricte użytkowego także walory estetyczne, w przypadku, kiedy były odpowiednio zdobione (Drożdż, Caputa, 2003, s. 357). Niestety te aspekty są najczęściej nieuchwytne w trakcie badań wykopaliskowych stanowisk pradziejowych.

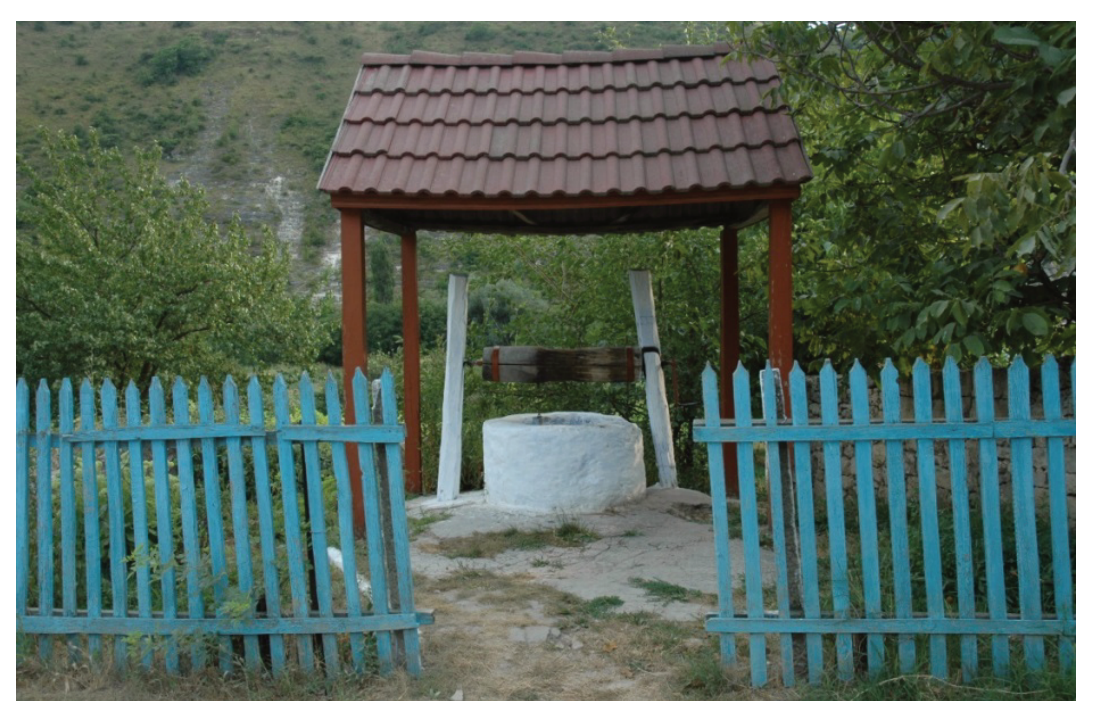

Ryc. 8. Studnia z Mołdawii z miejscowości Orheiul Vechi (Stary Orgiejów) jako przykład grodzenia tego typu obiektów (fot. A. Michałowski).

Fig. 8. The well from Moldova, from place Orheiul Vechi as an example of the fencing such features (photo by A. Michałowski).

W przestrzeni osady kultury przeworskiej w Kwiatkowie studnie towarzyszyły nieznacznie zagłębionym budynkom słupowym. Stanowiły one niewielkie kompleksy - grupy obiektów będące podstawową strukturą zabudowy przestrzeni tego stanowiska (Kot, Piotrowska, 2016, s. 295; Piotrowska, 2018). Tego typu lokalizacja znajduje analogię $\mathrm{w}$ strefie położonej na zachód od obszarów zajętych przez kulturę przeworską. W kręgu nadłabskim studnie odkrywane $\mathrm{w}$ obrębie osiedli łączone są z przestrzenią zagrody. Tym samym ich nierównomierna lokalizacja $\mathrm{w}$ obrębie poszczególnych stanowisk wiąże się z siecią zagród, jaka była właściwa dla konkretnej osady (Leube, 2009, s. 162). 
W bezpośrednim sąsiedztwie studni mogły się także znajdować np. poidła dla zwierząt. Niestety były to „urządzenia” naziemne, niepozostawiające po sobie czytelnych śladów. Obiekty o tego typu przeznaczeniu mogły być lokowane w strefie peryferycznej osady, w kontekście położonych tam pastwisk. W tym miejscu można przytoczyć przykład stanowiska w Kwiatkowie, gdzie oprócz studni tworzących struktury zagrodowe z półziemiankami mamy także do czynienia z pojedynczymi, oddalonymi od innych obiektów ujęciami wody, które można wiązać z pojeniem zwierząt hodowlanych (Piotrowska, Forysiak, Okupny, Twardy, 2018).

\section{FUNKCJE PELNIONE PRZEZ STUDNIE}

Funkcje studni to zagadnienie, które nierozerwalnie wiąże się z lokalizacją takich założeń w przestrzeni osady. Wbrew wszystkiemu wykorzystanie tego typu obiektów nie jest tak jednoznaczne, jak mogłoby się wydawać. W przeszłości spełniały one bowiem różnorodne funkcje, często także o szczególnym znaczeniu².

Studnie rejestrowane w trakcie badań archeologicznych w większości przypadków służyły po prostu jako ujęcie wody, a ich budowa podyktowana była względami pragmatycznymi. Już samo określenie „studnia” w pierwszej kolejności słusznie nasuwa skojarzenie z pozyskiwaniem czystej, świeżej wody do celów konsumpcyjnych. Określenie „studnia” staje się nieco konwencjonalne, patrząc na zróżnicowanie funkcjonalne tych obiektów. Warto zaznaczyć, że tytułowe obiekty spotykane są zarówno w osadach pozbawionych dostępu do naturalnych zbiorników i cieków wodnych, jak i na stanowiskach dogodnie zlokalizowanych pod względem hydrologicznym (Piotrowska, 2015).

Już w samej kwestii czerpania wody ze studni w literaturze przedmiotu często podnoszony jest problem, czy wszystkie tego typu obiekty istotnie były źródłem poboru wody z ujęć głębinowych, czy może część z nich jest jedynie zbiornikami na wodę deszczową (zob. Nowakowski, Waluś, 1986, s. 55; Michalski, 1983, s. 164; Skowron, 2014, s. 110-116).

Poza miejscem poboru (i magazynowania) wody pitnej dla osiedla, studnie pełniły także inne ważne funkcje w ekonomice społeczności pradziejowych. Obiekty tego typu wykorzystywane były często na potrzeby rzemiosł wymagających użycia wody. Identyfikacja taka pojawia się szczególnie często w przypadku stanowisk z dużą ilością obiektów studziennych w obrębie przebadanego obszaru (zob. Piotrowska, 2015). Często wymieniana jest tu ich rola jako roszarni lnu. Dzieje się tak szczególnie w odniesieniu do obiektów o plecionkowych konstrukcjach (por. Bednarczyk, 1988; Siciński, Stasiak, 2004, s. 100, 101, ryc. 8; Nierychlewska, Tyszler,

\footnotetext{
${ }^{2}$ Zagadnienie funkcji studni zostanie tu jedynie zasygnalizowane, ponieważ jest tematem oddzielnego artykułu będącego $\mathrm{w}$ trakcie przygotowywania.
} 
2009, s. 105, 107), które traktowane są jako rzadkość w przestrzeni stanowisk kultury przeworskiej (Nowakowski, Waluś, 1986, s. 46). Te o cembrowinie z wydrążonych pni drzew oraz o konstrukcji zrębowej uważane są za studnie właściwe (zob. Nowakowski, Waluś, 1986).

Na stanowiskach związanych z metalurgią studnie mają być z kolei elementem zaplecza towarzyszącego produkcji żelaza. Jako obiekty pomocnicze mają być składnikiem „,infrastruktury” związanej z piecowiskami (m.in. Zawisza, 1983, s. 45; Pazda, 1990, s. 46; Orzechowski, 2013, s. 217, 218, ryc. 113).

Część z tych obiektów po zaprzestaniu funkcjonowania jako sztuczne ujęcie wody często zmieniała swoje pierwotne przeznaczenie i stawała się np. jamą śmietniskową. Studnie mogły też pełnić więcej niż jedną funkcję. Otóż mogły być ujęciem wody i jednocześnie miejscem przechowywania produktów żywnościowych ze względu na niską temperaturę panującą nad poziomem wody. Warto też wspomnieć o funkcji społecznej, jaką pełniły studnie. Obiekty te, znajdując się w centrum osad, były ważnym miejscem w przestrzeni. Prawdopodobnie były miejscem spotkań.

Bogata symbolika wody, a co za tym idzie także samych studni, sprawia, że mogły one pełnić także role w rytuałach wykorzystujących je społeczności, będąc np. miejscem pochówków. Z taką sytuacją mamy do czynienia w przypadku jednej ze studni rozpoznanych na osadzie kultury przeworskiej w Konarzewie (Makiewicz i in., 2008).

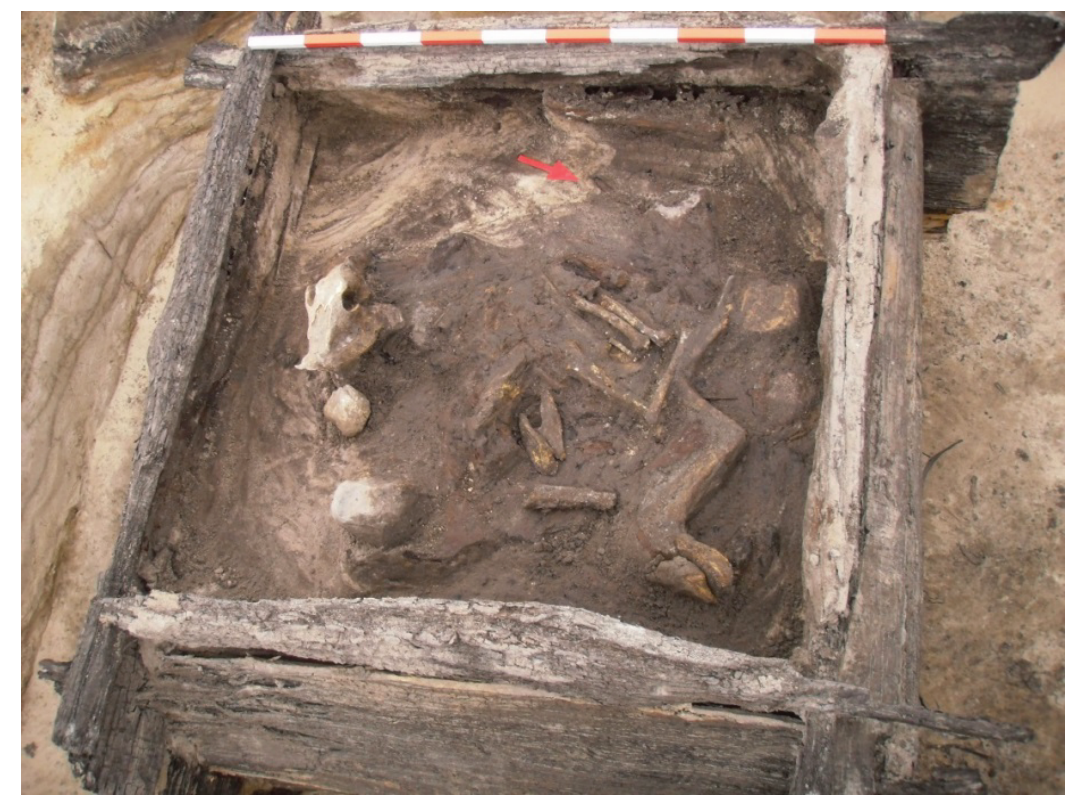

Ryc. 9. Studnia ze szczątkami psa ze stanowiska Kwiatków 11/20, gmina Brudzew (fot. E. Shellner).

Fig. 9. The well with the dog remains from Kwiatków site 11/20, Brudzew commune (photo by E. Shellner). 
Obiekty te były także miejscem deponowania ofiar składanych ze zwierząt. W studniach z okresu wpływów rzymskich występują szczątki psów - zarówno kompletne szkielety (ryc. 9), jak i pojedyncze kości oraz innych zwierząt (zob. Gralak, 2012; Piotrowska, 2016). W Konarzewie w jednej ze studni zdeponowany został kozioł sarny (Makiewicz i in., 2008).

\section{SYMBOLIKA I ZNACZENIE STUDNI}

Przywołany w ostatnim akapicie poprzedniego rozdziału aspekt symbolicznych funkcji obiektów studziennych wprowadza nas $\mathrm{w}$ jedno $\mathrm{z}$ ciekawszych naszym zdaniem zagadnień związanych z ich badaniem. Studnie to źródła charakteryzujące się niezwykle bogatą symboliką (Arendt, 1971; Kowalski, 1998, s. 535-538; Köhler, 2016). Nie sposób przytoczyć wszystkich znaczeń tych obiektów, ale warto zwrócić uwagę na niektóre wybrane aspekty sacrum z nimi związane. Jest to podyktowane tym, że woda u społeczeństw pradziejowych miała szczególną pozycję (zob. Woźny, 1996). W kulturze ludowej żywioł ten także ma wiele znaczeń - woda ma przede wszystkim moc oczyszczającą i uzdrawiającą (zob. Moszyński, 1967; Tylkowa, 1983; Grabińska-Szczęśniak, 2003; Labeda, 2003). Ludzie po wodę udawali się właśnie m.in. do studni.

$\mathrm{Z}$ analogii etnograficznych wiadomo, że studnię traktowano w sposób szczególny. Po pierwsze w jej głębinach znajdowała się woda, po drugie postrzegana była jako droga łącząca sferę sacrum i profanum - była obiektem o charakterze mediacyjnym. Studnie miały wiele znaczeń symbolicznych w tradycji ludowej - były tematem podań i legend. Jak pisze P. Kowalski: „znaczenie studni związane jest przede wszystkim z wypełniającą jej głębię wodą, której lustro stanowi ostateczną granicę...” oraz „Studnia wykopana w ziemi i prowadząca w dół, w ciemność, do krainy zmarłych, jest drogą, którą można przekroczyć granice ludzkiego świata" (Kowalski, 1998, s. 535). W przypadku studni mamy do czynienia z sytuacją, gdy obiekt ten jako element kulturowy nabiera cech drugiego elementu kulturowego, czyli wody. Sprawia to, że czynności związane ze studnią nabierają szczególnych właściwości. Studnia to miejsce przenikania się dwóch światów (Kowalski, 1998, s. 537). To szczególny obiekt stanowiący w wielu kulturach axis mundi - łączy niebo z ziemią i światem podziemnym, czyli ma charakter mediacyjny (Kopaliński, 1990, s. 406; Kowalski, 1998, s. 535). Obiekty te były także siedzibą topielców i złych mocy, stąd np. zakaz zaglądania do studni.

Studnie spotykane są w miejscach świętych, gdzie stanowią „centrum świata” (Kowalski, 1998, s. 535); w różnych religiach odgrywały też szczególną rolę. Motyw studni pojawia się np. na kartach Starego Testamentu - przy studni dochodzi najczęściej do spotkań. Obiekty te znajdowały się na cmentarzach. Niekiedy traktowano wodę ze studni jako mającą szczególne właściwości. Studnie są także elementem legend i bajek, a także są obecne w przysłowiach (Gralak, 2012, s. 122). 
Potwierdzenie szczególnego znaczenia studni znajdujemy również w źródłach archeologicznych - były to nie tylko miejsca poboru wody, ale także składania ofiar, a także niekiedy pochówków (Makiewicz i in., 2008; Gralak, 2012). W literaturze można spotkać pogląd, że studnie bez widocznej obudowy uważane są za miejsca, w których deponowano ofiary (Leube, 2009, s. 164).

Naturalne źródła szczególnie dużą rolę odgrywały w wierzeniach i praktykach religijnych Celtów. Znajdowane są w nich licznie dary wotywne, m.in. w postaci drewnianych oraz metalowych przedmiotów, w których można się dopatrzyć przedstawień fragmentów ludzkiego ciała (Dillon, Chadwick, 1975, s. 132). W ich wnętrzu znajdowane są różne zabytki, jak np. drewniane rzeźby przedstawiające zwierzęta, które świadczą o rytualnym wykorzystywaniu tychże obiektów (Schlette, 1979, s. 196; Cunliffe, 1997, s. 200; Wieland, 2002, s. 22-23). Ich obecność w środowisku wodnym wiąże się zapewne z uzdrawiającą mocą wody. Wiadomo, że większość źródeł wiązała się z żeńskimi bóstwami, co znajduje swoje odzwierciedlenie w późniejszych związkach studni oraz źródełek z terenów zachodnich Europy z chrześcijańskimi świętymi płci żeńskiej. Nie przez przypadek większość rzek np. we Francji ma żeńskie nazwy własne (Cunliffe, 1997, s. 198, 199). W mitach celtyckich pojawia się studnia, przy której młody król spotyka boginię pod postacią pięknej kobiety (Powell, 1999, s. 150). Szczególna rola wody u Celtów widoczna jest m.in w licznie znajdowanych darach i ofiarach w rzekach, jeziorach i źródłach. W przypadku szybów (ang. shaft) o znacznej głębokości, sięgających poniżej poziomu wód gruntowych, nie jest do końca pewne, czy pierwotnie służyły one jako studnie, czy też zostały wykopane w celu praktyk rytualnych. Oczywiście mogły służyć jako jedno i drugie (Cunliffe, 1981, s. 91-93; 1997, s. 201, ryc. 161). Wspomniane szyby interpretowane są jako obiekty będące „łącznikami” z bóstwami (Piggot, 2000, s. 72).

\section{MIEJSCE STUDNI W PRZESTRZENI OSAD}

Ze znaczeniem tych obiektów oraz ich symboliką nierozerwalnie łączy się ich usytuowanie $\mathrm{w}$ obrębie osad. $\mathrm{Z}$ częściowym jedynie rozpoznaniem przestrzeni reliktowych wiąże się nieodzownie problem lokalizacji studni w obrębie stanowisk. Na podstawie jedynie przebadanego fragmentu osiedla trudno wnioskować na temat jego kompleksowej struktury przestrzennej. Brak studni na przebadanych stanowiskach należy wiązać nie tylko $\mathrm{z}$ ich częściowym poznaniem, ale także z tym, że obiekty te znajdowały się czasem poza zwartą zabudową, co można odnieść do osad z różnych odcinków pradziejów (por. Leube, 2009; Rzepecki, 2014, s. 111; Piotrowska, 2018). Studnie zajmowały odmienne miejsce w przestrzeni osiedli, co miało niewątpliwie związek $\mathrm{z}$ ich przeznaczeniem. Lokalizacja studni zależała od kilku czynników, które można podzielić na te naturalne - środowiskowe oraz antropoge- 
niczne (ryc. 10). Studnie odkrywane są w różnych częściach osad kultury przeworskiej, takich jak strefy gospodarcze związane z rzemiosłem, rolnictwem, hodowlą oraz w strefach mieszkalnych (Michałowski, 2003, s. 145). Obie z wymienionych stref często przenikały się $\mathrm{w}$ obrębie użytkowanej przestrzeni i trudno je czasem rozdzielić. Mamy wtedy do czynienia z obszarem mieszkalno-gospodarczym, w którym także rejestrowano tytułowe obiekty. Ostatnia ze stref, w obrębie której studnie lokalizowano, to strefa produkcyjna - w przypadku okresu wpływów rzymskich często związana z produkcją metalurgiczną (Piotrowska, 2018). Rozmieszczenie studni w pewnym stopniu odzwierciedlało więc strukturę mieszkalną i gospodarczą osady.

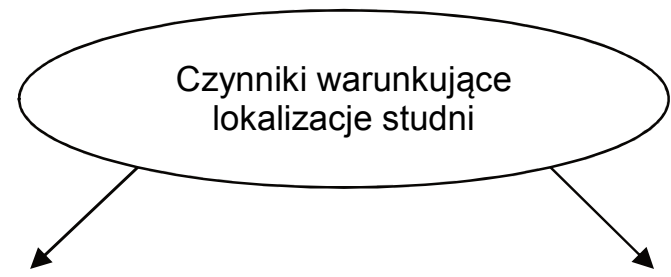

Naturalne/środowiskowe:

Antropogeniczne:

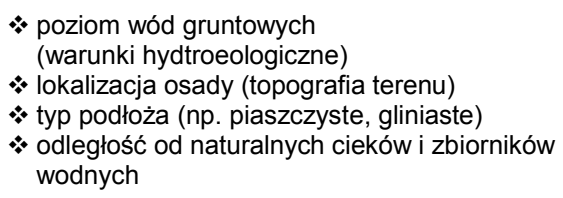

* wielkość i charakter osady

* organizacja wewnętrzna osady (struktura zagospodarowania przestrzeni

* elementy wierzeń

* wiedza i umiejętności budowniczych studni

* czynniki i wpływy kulturowe (tradycje lokalne, obce oddziaływannia)

Ryc. 10. Czynniki mające wpływ na lokalizację studni w przestrzeni osad (rys. M. Piotrowska).

Fig. 10. The factors of the well location within the space of the settlement (by M. Piotrowska).

$\mathrm{Na}$ osadach kultury przeworskiej dominują studnie pojedyncze, które można uznać za „publiczne-wspólne”, mające na celu zaopatrywanie w wodę wszystkich mieszkańców osady. Niekiedy odnotowywano obecność dwóch, rzadziej kilku lub kilkunastu sztucznych ujęć wody łączonych z jedną fazą osadniczą. Studnie o charakterze ,prywatnym” odnotowywane są rzadziej (Piotrowska, 2018). Ze studniami prywatnymi - należącymi do pojedynczych nieznacznie zagłębionych budynków oraz ze studniami wspólnymi - odizolowanymi od pozostałych obiektów i służącymi prawdopodobnie do pojenia zwierząt mamy do czynienia w przypadku stanowiska w Kwiatkowie (Piotrowska i in., 2018). Taki podział tych obiektów spotykany był jeszcze w XX wieku, gdy w wielu wsiach i miasteczkach obok studni prywatnych funkcjonowały gminne wspólne ujęcia wody (Drożdż, Caputa, 2003, s. 353, 354).

Na wybrany typ zabudowy, a tym samym na miejsce studni w przestrzeni osady miały wpływ nie tylko czynniki środowiskowe, ale zapewne też kulturowe (por. Michałowski, 2003, s. 150). Jak już wyżej wspomniano, poszczególne ujęcia wody rejestrowane na osadach przypisywane są zagrodom znajdującym się w ich sąsiedz- 
twie. W przypadku niewielu osiedli widoczna jest rozbieżność ilościowa między małą liczbą studni a licznymi zagrodami (Leube, 2009, s. 162). Tak jest np. w przypadku Feddersen Wierde, gdzie odkryto jedynie trzy sztuczne ujęcia wody (Haarnagel, 1979, s. 168). Z neolitu znane są długo istniejące osiedla użytkowane przez wiele pokoleń z bardzo dużą liczbą odkrytych domostw, gdzie rejestrowano jedynie pojedyncze studnie, np. osada w Eythra, istniejąca przez kilka stuleci, gdzie zarejestrowano łącznie około 300 domów i zaledwie dwie studnie, czy też stanowisko Leipzig/Halle (Elburg, 2011, s. 28).

Podsumowując, zagospodarowanie przestrzenne osady, a tym samym wybór miejsca pod studnię podyktowany był, co nie budzi wątpliwości, względami pragmatycznymi, ale także prawdopodobnie odzwierciedlał pewną wizję obrazu struktury świata, jaką mieli jej mieszkańcy.

Warto wspomnieć, że przy lokalizacji studni z omawianego okresu nie kierowano się zasadami higieny. Zasady ochrony ujęć wody przed czynnikami zewnętrznymi zaczęto brać pod uwagę na wsiach dopiero w XX wieku, które m.in. zalecały budowę studni w możliwie jak najwyższym miejscu w stosunku do otaczającego terenu czy poza sąsiedztwem budynków przeznaczonych dla zwierząt i jam odpadkowych (Podrez, 1984, s. 4-5). Wiele wskazuje, że często już w czasach późniejszych wystrzegano się spożycia wody bezpośrednio zaczerpniętej ze studni. Zaczęto zdawać sobie sprawę ze złej jakości wody, zwłaszcza w miejscach gęsto zaludnionych (ryc. 11).

Ryc. 11. Rysunek ukazujący stan zanieczyszczenia studni wynikający z braku zabezpieczenia wlotu studziennego (za: A. Szniolis, 1955, s. 33, ryc. 5).

Fig. 11. Drawing showing the state of the contamination of the well due to the lack of the well protection (by A. Szniolis, 1955, p. 33, fig. 5).

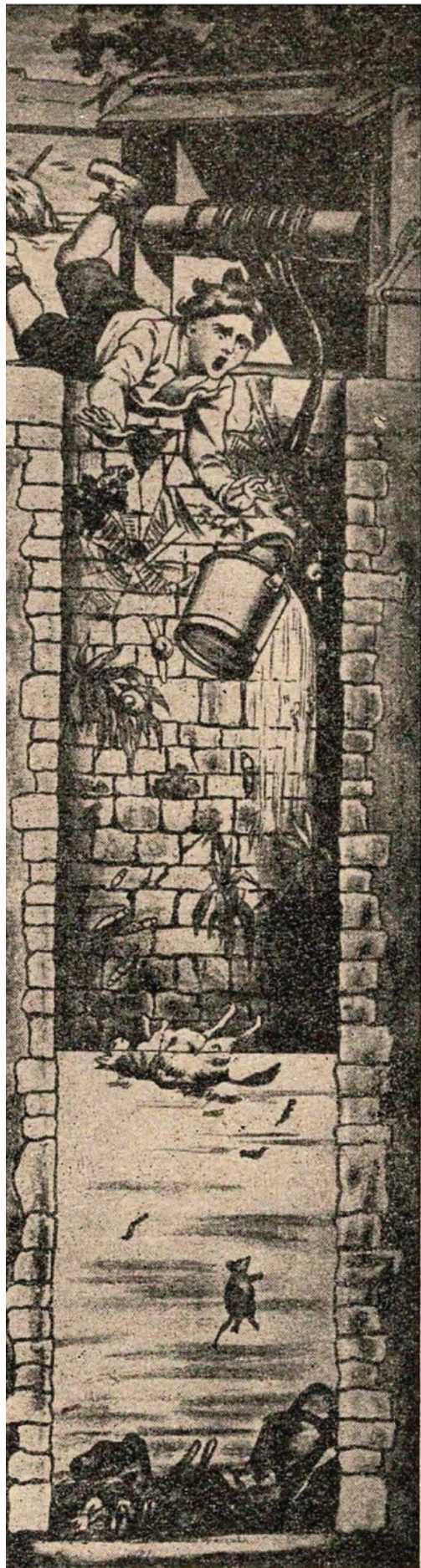




\section{PODSUMOWANIE - MOŻLIWOŚCI BADAWCZE}

Większość publikacji wzmiankujących studnie ogranicza się jedynie do podania wymiarów obiektów oraz konstrukcji w przypadku zachowanych cembrowin. Niezmiernie rzadko można znaleźć dane pozwalające na podjęcie próby uściślenia funkcji tych obiektów oraz etapów ich użytkowania, a także jego zaniechania. Układ warstw podepozycyjnych jest nam w stanie wiele powiedzieć o charakterze ,życia i śmierci" danego obiektu - czy studnie były czyszczone (ilokrotnie?), czy zostały porzucone, a może wtórnie wykorzystywano je jako jamy śmietnikowe czy też zostały celowo zasypane, a może ulegały powolnemu procesowi samozasypywania (ryc. 12). Podobnie jest w przypadku śladów zachowania naziemnych części studni i ich ewentualnych napraw czy też możliwości rozbierania górnych partii cembrowiny w celu wtórnego użycia budulca.

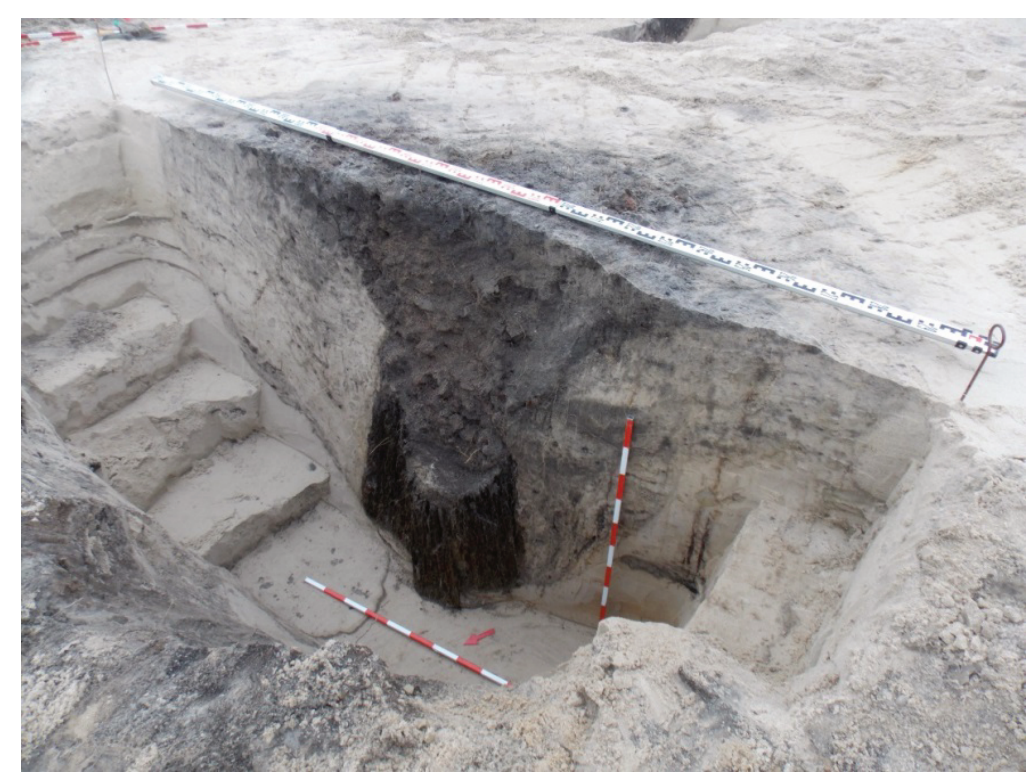

Ryc. 12. Przykład studni celowo zasypanej, stanowisko Kwiatków 11/20, gmina Brudzew (fot. E. Shellner). Fig. 12. Example of the well intentionally backfilled, Kwiatków 11/20, Brudzew commune (photo by E. Shellner).

Niestety te same krytyczne uwagi należy wystosować do sposobu prezentacji zabytków pochodzących ze studni. Informacje o ich lokalizacji w obrębie wypełniska, stanie zachowania - stopniu zniszczenia - nie są satysfakcjonująco oddawane przy omawianiu zawartości wypełnisk studziennych. Osobnym problem jest częsty brak opublikowania tych obiektów po zakończeniu badań archeologicznych. 
Osady, w szczególności te, które zakładane były na obszarach, gdzie nie było dostępu do źródeł nadającej się do spożycia wody napowierzchniowej, musiały mieć dostęp do wód podziemnych w postaci studni. Można się domyślać, że jedną $\mathrm{z}$ pierwszych czynności po osiedleniu się w takim miejscu była właśnie budowa sztucznego ujęcia wody. $Z$ tego powodu najwcześniejsze daty uzyskane dzięki analizom dendrochronologicznym $\mathrm{z}$ drewna budującego cembrowiny można korelować z początkiem powstania danej osady. Należy jednak mieć na uwadze to, że w przypadku datowania drewna pozyskanego z cembrowin łatwo wpaść w ,pułapkę dendrochronologiczną”. Otóż o wiarygodnym datowaniu takiej studni możemy mówić jedynie wówczas, gdy uzyskamy daty ze wszystkich lub z większości desek budujących cembrowinę i gdy daty te są do siebie zbliżone, czyli gdy uzyskamy serię prób z badanego materiału (Zielski, Krapiec, 2004, s. 128). Wynika to z tego, że do budowy studni można było użyć budulca wtórnie, stąd czasem znaczne różnice w datowaniu poszczególnych elementów budujących cembrowinę. $\mathrm{Z}$ przykładem ponownego wykorzystania drewna do budowy studni mamy do czynienia np. w przypadku studni kłodowej odkrytej na stanowisku w Berlinie-Lichterfelde, gdzie jako cembrowiny użyto pnia, który wcześniej służył jako ul (Michalski, 1983, s. 164). Z tego względu ważna jest też korelacja ustaleń typologicznych dla zabytków pozyskanych ze studni wraz z wynikami datowań metodą dendrochronologiczną bądź C14.

Badania studni pozwalają uchylić także rąbka wiedzy na temat sytuacji środowiskowej panującej nie tylko w przestrzeni osady, lecz także w jej pobliżu. Próbki zawierające materiał z wypełnisk studni dają możliwość wykonania szeregu analiz, takich jak badania palinologiczne czy makroszczątków roślin ustalających obraz ekosystemu osady. Identyfikacja szaty roślinnej może wskazać miedzy innymi na typ gospodarki prowadzonej przez społeczność, która wybudowała ową studnię. Analizy geochemiczne to kolejne badania, które pozwalają na ocenę jakości i składu chemicznego wody czerpanej ze studni. Sprawia to, że obiekty mogą dostarczyć wielu cennych danych pozwalających na próbę odtworzenia środowiska wokół danej osady.

\section{ZAKOŃCZENIE}

W czasach współczesnych studnie utraciły swój wyjątkowy charakter. Coraz rzadziej można je spotkać w krajobrazie wsi i miast europejskich, głównie na obszarach słabiej rozwiniętych. Wraz z postępem technologicznym przestały być źródłem wody niezbędnej do życia. Zanieczyszczenie środowiska spowodowało, że wody podskórne, które zaopatrywały większość studni, w znacznej części przestały być zdatne do wykorzystania spożywczego. Klasyczne studnie odchodzą tym samym powoli w zapomnienie, znajdując swoje miejsce w skansenach. Wraz z nimi przemija także ich szczególne znaczenie i bogata symbolika. Można ją jeszcze odnaleźć 
w niektórych świątyniach, gdzie spotykane są studnie ujmujące w swoje cembrowiny cudowne źródła. Jedną z takich właśnie obiektów jest studnia z kościoła Najświętszej Krwi Pana Jezusa przy ul. Żydowskiej w Poznaniu (ryc. 13).

Studnie w przestrzeni stanowisk archeologicznych to nie tylko ujęcia wody, ale tak naprawdę niezwykle uniwersalne obiekty o szerokim przeznaczeniu zarówno utylitarnym, jak również znaczącej strefie symbolicznej. To swoiste archiwa czasu pozwalające na przeprowadzenie wielu analiz specjalistycznych i podjęcie badań interdyscyplinarnych. Ich wyjątkowość sprawia, że są to jedne z ciekawszych obiektów badanych przez archeologa.

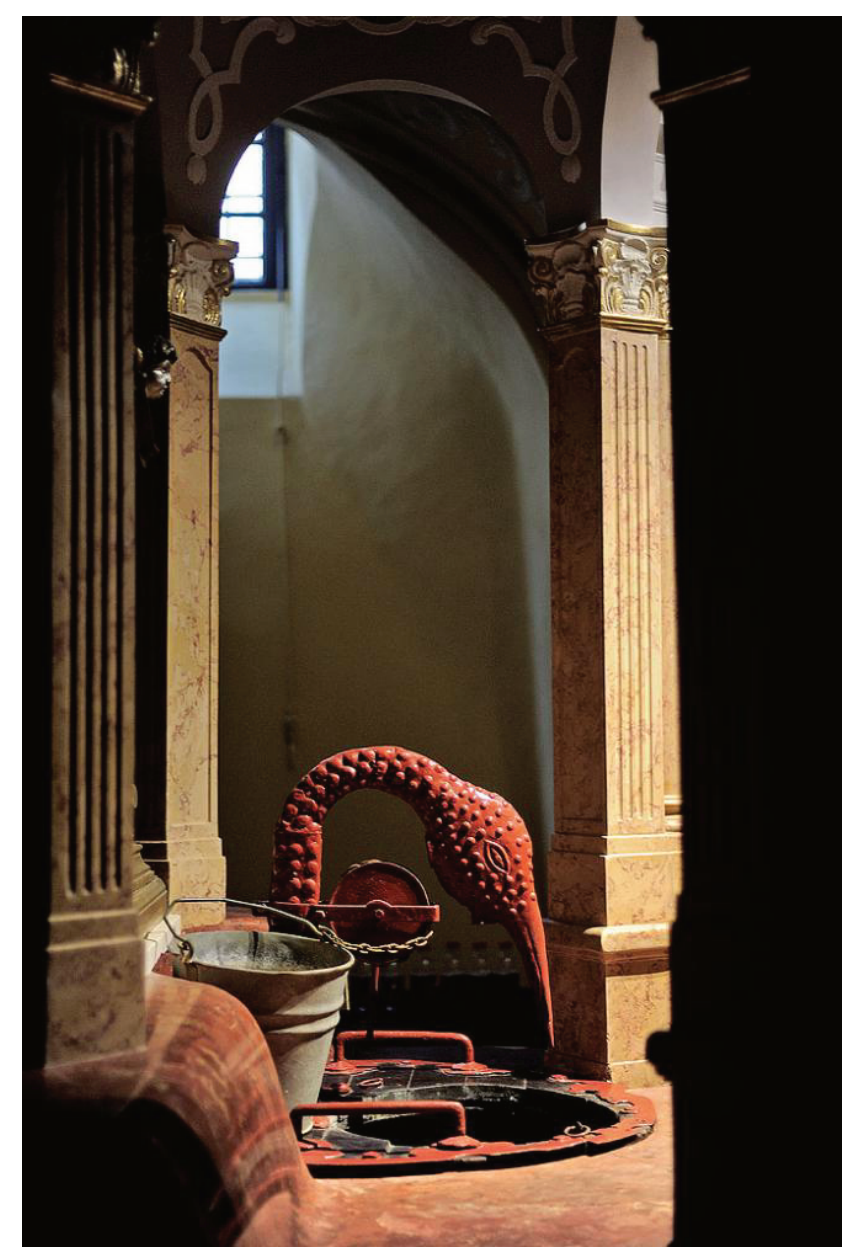

Ryc. 13. Studnia z wodą o uzdrawiającej mocy z kościoła Najświętszej Krwi Pana Jezusa w Poznaniu (http://www.trzyhostie.pl/29,0,o-kosciele.html).

Fig. 13. The well with the water of healing power from the church Najświętszej Krwi Pana Jezusa in Poznań (http://www.trzyhostie.pl/29,0,o-kosciele.html, acces on the 15th of March 2018). 


\section{BIBLIOGRAFIA}

Albrecht, N.

2014 Römerzeitliche Brunnenund Brunnenfunde im rechtsrhenischen Obergermanien und in Rätien [Maszynopis pracy doktorskiej. Mannheim: Univ. Heidelberg].

Arendt, D.

1971

Das Symbol des Brunnenszwischen Antikeund Moderne. Weltund Wort, 26, 286-297.

Baatz, A.

1981 Stichwort „Brunnen”. W: J. Hoops (red.), Reallexikon der germanischen Altertumskunde (t. 4, s. 3-7). Berlin: Verlag von Karl J. Tübner.

Baron, J.

2014 Osada z młodszego okresu przedrzymskiego, okresu wpływów rzymskich i wędrówek ludów. W: M. Masojć (red.), Obozowiska, osady, wsie. Wrocław - Widawa 17 (s. 267312). Wrocław: Uniwersytet Wrocławski.

Bączyński, J.

2000 Studnie z okresu wplywów rzymskich na obszarze Polski i Niemiec [Maszynopis pracy magisterskiej w archiwum Instytutu Archeologii UAM w Poznaniu].

Beck, H.

1918/1919 Brunnen. W: J. Hoops (red.), Reallexikon der germanischen Altertumskunde (t. 1). Strasburg: Verlag von Karl J. Tübner.

Biermann, F.

2001 Der Brunnenbau des 7/8. Bis 11/12. Jahrhunderts bei den nördlichen Westslawen (Polen Und Ostdeutschland). Ethnographisch-Archäologische Zeitschrift, 42, 211-264.

Brückner, A.

1927 Stownik etymologiczny języka polskiego. Kraków: Krakowska Spółka Wydawnicza.

Cembrzyński, P.

2011 Ze studiów nad życiem w średniowiecznym mieście. Zaopatrzenie w wodę i usuwanie nieczystości w miastach stref bałtyckiej i sudecko-karpackiej w XIII-XVI wieku. Wratislavia Anitiqua, 14.

Cunliffe, B.

1981 L'univers des Celtes. Paris: Du Fanal.

Cunliffe, B.

1997 The Ancient Celts. Oxford - New York, NY: Penguin Books.

Czerniak, L., Kabaciński, J.

2004 Archeologiczne badania ratownicze Instytutu Archeologii i Etnologii PAN w Poznaniu na trasie autostrad A1 i A2 w Wielkopolsce i na Kujawach w roku 2001-2002. Raport 2001-2002. Zeszyty Ośrodka Ochrony Dziedzictwa Archeologicznego (d. Zeszyty ORBA). Wstepne wyniki konserwatorskich badań ratowniczych $w$ strefie budowy autostrad w Polsce za lata 2001-2002 (s. 140-155). Warszawa: Ośrodek Ochrony Dziedzictwa Archeologicznego.

Dillon, M., Chadwick, K.

1975 Ze świata Celtów. Warszawa: Państwowy Instytut Wydawniczy.

Drożdż, A., Caputa, Z.

2003 Studnie w krajobrazie kulturowym polski na podstawie Polskiego Atlasu Etnograficznego. W: A. Jankowski, U. Myga-Piątek, G. Jankowski (red.), Problemy ochrony środowiska i ksztaltowania krajobrazu Górnego Śląska na tle doświadczeń z innych regionów Polski (s. 353-366). Sosnowiec: Wydział Nauk o Ziemi Uniwersytetu Śląskiego: Komisja Krajobrazu Kulturowego Polskiego Towarzystwa Geograficznego. 
Elburg, R.

2011 Weihwasseroder Brauchwasser? Einige Gedanken zur Funktionbandkeramischer Brunnen. Archäologische Informationen, 34(1), 25-37.

Galili, E., Sharvit, J.

1998 Submerged Neolithic Water-Wells from the Carmel Coast of Israel. W: H. Koschik (red.), Brunnen der Jungsteinzeit (s. 31-44). Köln-Bonn: Rheinland-Verlag in Kommission bei Dr. Rudolf Habelt.

Gaude, B.

1995 Brunnenanlagen der römischen Kaiserzeit Und frühenVolkerwanderungszeit (VI-V Jahrhundert) in Norddeutchland [Maszynopis pracy magisterskiej w archiwum Uniwersytetu w Kilonii].

Grabińska-Szczęśniak, A.

2003 Użytkowanie i symbolika wody na pograniczu łemkowsko-bojkowskim w latach 30-tych XX wieku. W: A. Jankowski, U. Myga-Piątek, G. Jankowski (red.), Problemy ochrony środowiska i ksztaltowania krajobrazu Górnego Ślaska na tle doświadczeń z innych regionów Polski (s. 401-408). Sosnowiec: Wydział Nauk o Ziemi Uniwersytetu Śląskiego: Komisja Krajobrazu Kulturowego Polskiego Towarzystwa Geograficznego.

Gralak, T.

2012 „Użył jak pies w studni”, czyli o pochówkach zwierzęcych z osady w Polwicy-Skrzypniku, pow. Oława, z późnego okresu wpływów rzymskich i początku okresu wędrówek ludów. Przegląd Archeologiczny, 60, 107-132.

Greif, J.

2015 Die Brunnenbefunde des mehr periodigen Fundplatzes Buschow 8, Lkr. Havelland [MaGrimm, J., Grimm, W. szynopis pracy magisterskiej w archiwum Uniwersytetu w Berlinie - Freie Universität].

1860 Deutsches Worterbuch. Zweiter Band. Leipzig: Verlag von S. Hirzel.

Haarnagel, W.

1979 Die Grabung Feddersen Wierde. Die Ergebnisse der Ausgrabungen der vorgeschichtlichen Wurt Feddersen Wierdebei Bremerhaven in den Jahren 1955 bis 1963. Feddersen Wierde (t. 2). Wiesbaden: Franz Steiner Verlag.

Jiao, J. J.

2007 A 5600-year-old wooden well in Zhejiang Province, China. Hydrogeology Journal, 15, 1021-1029.

Jurkiewicz, B., Machajewski, H.

2006 Osadnictwo kultury przeworskiej z przełomu er oraz późnego okresu rzymskiego i wczesnej fazy okresu wędrówek ludów. W: L. Czerniak, J. Gąssowski (red.), Osada wielokulturowa w Jankowie, gmina Piątek, województwo łódzkie (s. 109-218). Pułtusk: Instytut Archeologii Uniwersytet Gdański, Instytut Antropologii i Archeologii Akademii Humanistycznej im. Aleksandra Gieysztora.

Kałagate, S. Jaszewska, A.

2005-2006 Wstępne wyniki badań wykopaliskowych na trasie planowanej obwodnicy Nowej Soli, w ramach drogi krajowej nr 3. W: S. Kadrow (red.), Raport 2005-2006 (s. 437-485). Warszawa: Narodowy Instytut Dziedzictwa.

Kot, K., Piotrowska, M.

2016 Chronologia i zagospodarowanie stref A1 i A2 w okresach przedrzymskim, rzymskim i wędrówek ludów. W: S. Rzepecki (red.), Wielokulturowy kompleks osadniczy ze stanowiska Kwiatków 11/20. Strefy A1 i A2 (s. 287-301). Łódź: Instytut Archeologii Uniwersytetu Łódzkiego, Fundacja Uniwersytetu Łódzkiego, Łódzka Fundacja Badań Naukowych. 
Kopaliński, W.

$1990 \quad$ Stownik symboli. Warszawa: Wiedza Powszechna.

Koschik, H. (red.)

1998 Brunnen der Jungsteinzeit Internationales Symposium Erkelenz. 27. bis 29. Oktober 1997. Materialien zur Bodendenkmalpflege im Rheinland IL Köln/Bonn. Köln - Bonn: Rheinland-Verlag in Kommission bei Dr. Rudolf Habelt.

Kowalski, P.

1998 Leksykon znaki świata. Omen, przesąd, znaczenie. Warszawa - Wrocław: Wydawnictwo PWN.

Köhler, K.

2016 Der Brunnen als Strukturelement der Identitätsgenese. W: R. Triebskorn, J. Wertheimer (red.), Wasser als Quelle des Lebens. Eine multidisziplinäre Annäherung (s. 125-139). Berlin: Springer Spektrum.

Krzyszowski, A.

2012 Studnia z późnej epoki brązu ze Szczodrzykowa koło Kórnika. Folia Praehistorica Posnaniensia, 17, 219-242.

Labeda, A.

2003 Symboliczno-magiczne znaczenie wody w tradycyjnej kulturze wsi polskiej. W: A. Jankowski, U. Myga-Piątek, G. Jankowski (red.), Problemy ochrony środowiska ksztaltowania krajobrazu Górnego Ślaska na tle doświadczeń z innych regionów Polski (s. 137-151). Sosnowiec: Wydział Nauk o Ziemi Uniwersytetu Śląskiego: Komisja Krajobrazu Kulturowego Polskiego Towarzystwa Geograficznego.

Leube, A.

2009 Studien zu Wirtschaft Und Siedlung bei den germanischen Stämmen im nördlichen Mitteleuropa während des 1 . Bis 5/6. Jahrhunderts n. Chr. Römisch-Germanische Forschungen, 64 .

Lityńska-Zając, M., Wasylikowa, K.

2005 Przewodnik do badań archeobotanicznych. Poznań: Wydawnictwo Sorus.

Makiewicz, T., Kaczor, W., Krąpiec, M., Makowiecki, D., Miłosz, E., Polcyn, M.

2008 Studnia - cmentarzysko z okresu wędrówek ludów w obrębie kompleksu osadniczego w Konarzewie (stanowisko 5), pow. Poznań ziemski. Nowy typ cmentarzyska kultury przeworskiej. W: J. Skowron, M. Olędzki (red.), Kultura przeworska. Odkrycia - inter-

Michalski, J. pretacje - hipotezy (t. 2, s. 299-356). Łódź: Instytut Studiów Międzynarodowych UŁ.

1983 Zagadnienia systematyzacji i interpretacji obiektów nieruchomych (Ze studiów nad osadami otwartymi kultury łużyckiej). Materiały starożytne i wczesnośredniowieczne, 5, 135-196.

Michałowski, A.

2003 Osady kultury przeworskiej z terenów ziem polskich. Poznań: Wydawnictwo Poznańskie. Minichreiter, K.

1998 The Oldest Neolithic Water-Well in Croatia from the Early Starč Settlement near Slavonski Brod. W: H. Koschik (red.), Brunnen der Jungsteinzeit (s. 25-29). Köln-Bonn: Rheinland-Verlag in Kommission bei Dr. Rudolf Habelt.

Moszyński, K.

1967 Kultura ludowa Stowian, t. 2: Kultura duchowa (cz. 1). Warszawa: Zakład Narodowy Ossolińskich.

Myga-Piątek, U.

2002 Zabytkowe studnie w krajobrazie Wyżyny Częstochowskiej. W: A. Jankowski, U. Myga-Piątek, G. Jankowski (red.), Problemy ochrony środowiska i ksztattowania krajobra- 
zu Górnego Śląka na tle doświadczeń z innych regionów Polski (s. 100-114). Sosnowiec: Wydział Nauk o Ziemi Uniwersytetu Śląskiego. Komisja Krajobrazu Kulturowego Polskiego Towarzystwa Geograficznego.

Nierychlewska, A., Tyszler, L.

2009 Badania w Witowie na stanowisku 14-15, gm. Piątek, pow. Łęczyca, woj. łódzkie, na trasie autostrady A1 (ST. A1 72-73). Zarys problematyki badań. Prace i Materiały Muzeum Archeologicznego i Etnograficznego w Lodzi, Seria Archeologiczna, 44, 103-124.

Noaman, M. N., El Quosy, D.

2017 Hydrology of the Nile and Ancien Agriculture. W: M. Satoh, S. Aboulroos (red.), Irrigated Agriculture in Egypt: Past, Present and Future (s. 9-28). Cham: Springer International Publishing.

Nowakowski, W., Waluś, A.

1986 Studnie kultury przeworskiej z ziem Polski. Światowit, 36, s. 43-64.

Orzechowski, S.

2013 Region żelaza. Centra hutnicze kultury przeworskiej. Kielce: Wydawnictwo Uniwersytetu Jana Kochanowskiego.

Pazda, S.

1990 Osada hutnicza z późnego okresu rzymskiego w Izbicku, woj. opole. Silesia Antiqua, 32, $23-50$.

Piggot, S.

2000 Druidzi. Warszawa: Wydawnictwo RTW.

Piotrowska, M.

2015 Studnia koło rzeki, czyli o zasadności budowy i funkcji sztucznych ujęć wody w przestrzeni osad kultury przeworskiej. Szkic do problemu. W: L. Tyszler, E. Droberjar (red.), Archeologia Barbarzyńców. Barbari Superiores et Inferiores (s. 329-343). Łódź - Wieluń: Muzeum Ziemi Wieluńskiej.

Piotrowska, M.

2016 Osadnictwo z okresu przedrzymskiego, okresu wpływów rzymskich i wczesnego okresu wędrówek ludów. Perspektywa źródeł nieruchomych. W: S. Rzepecki (red.), Wielokulturowy kompleks osadniczy ze stanowiska Kwiatków 11/20, gm. Brudzew. Strefy A1 i A2 (s. 47-140). Łódź: Instytut Archeologii Uniwersytetu Łódzkiego, Fundacja Uniwersytetu Łódzkiego, Łódzka Fundacja Badań Naukowych.

Piotrowska, M.

2017 Historia i stan badań nad studniami w okresie przedrzymskim, okresie wpływów rzymskich oraz w okresie wędrówek ludów na terenach ziem polskich. W: A. Marciniak-Kajzer, A. Andrzejewski, A. Golański, S. Rzepecki, M. Wąs (red.), Nie tylko krzemienie. Not onlyflints. Studia ofiarowane prof. Lucynie Domańskiej w 45-lecie pracy naukowodydaktycznej $i w 70$. rocznicę urodzin (s. 413-423). Łódź: Instytut Archeologii Uniwersytetu Łódzkiego, Łódzka Fundacja Badań Naukowych, Stowarzyszenie Naukowe Archeologów Polskich Oddział w Łodzi.

Piotrowska, M.

2018 The well - its place and importance in the settlements of the Central European communities representing the Late Antiquity - an example of the Przeworsk culture. Archäologisches Korrespondenzblatt. In press.

Piotrowska, M.

2018a Zaczerpnąć wody. Sposoby użytkowania studni w pradziejach na przykładzie znalezisk związanych z kulturą przeworską. W: K. Kot, M. Piotrowska, M. Olędzki, A. Michałowski (red.), Kultura przeworska. In press. 
Piotrowska, M., Forysiak, J., Okupny, D., Twardy, J.

2018 Public orprivate? Anattempt to interpret the social purpose of the well in the space of the Przeworsk culture settlement on the example of the site in Kwiatków. Sprawozdania Archeologiczne. In press.

Podrez, A.

1984 Studnie zagrodowe. Warszawa: Centralne Biuro Projektowo-Badawcze Budownictwa Wiejskiego.

Powell, T. G. E.

1999 Celtowie. Warszawa: RTW.

Rzepecki, S.

2014 Two water wells of the LBK culture from the north part of the site of Kruszyn 3/10, Włocławek commune. Analecta Archaeologica Ressoviensia, 9, 95-116.

Samuels, C.

2014 Technology in Mesopotamia. Lexile: Gareth Stevens Publishing.

Schmidt, Ch.

2003 Holzverschalte Brunnenvomersten Jahrhundert vor bis zumachten Jahrhundert nach

Christus in Deutschland [Maszynopis pracy magisterskiej w archiwum Uniwersytetu w Marburgu].

Schöneburg, P.

1996 Neue Aspekte zum Brunnenbau im germanischen Dorf von Dallgow-Döberitz, Lkr. Havelland. Veröffentlichungen des Museums für Ur Und Frühgeschichte, 30, 141-152.

Schlette, F.

1979 Kelten zwischen Alesia und Pergamon. Eine Kulturgeschichte der Kelten. Leipzig - Jena - Berlin: Urania-Verlag.

Szniolis, A.

1955 Studnie. Ich ochrona przed zanieczyszczeniem. Sposoby poprawy jakości wody na wsi. Warszawa: Państwowy Zakład Wydawnictw Lekarskich.

Tylkowa, D.

1983 Rola wody w wierzeniach i praktykach magicznych. Rocznik Muzeum Etnograficznego w Krakowie, 8, 84-89.

Wanzek, B.

1955 Eisenproduktion im: Handwerkeviertel. Eine Siedlung der Römischen Kaiserzeit bei Genshagen, Landkreis Teltow-Fläming. Archäologie in Berlin und Brandenburg 1993-1994, 101-102.

Weiner, J.

1998 Neolithische Brunne - Bemerkungen zur Terminologie, Typologie und Technologie mit einem Modell zur bandkeramischen Wasserversorgung. W: H. Koschik (red.), Brunnen der Jungsteinzeit (s. 193-216). Köln-Bonn: Rheinland-Verlag in Kommission bei Dr. Rudolf Habelt.

Weiner, J., Lehmann, J.

1998 Remarksconcerning Early Neolithic Woodworking: The Example of the Bandkeramik Well of Erkelenz-Kückhoven, Northrhine-Westfalia, Germany. W: L. Castelletti, A. Pessina (red.), Introduzione all'Archeologia degli Spazi Domestici. Atti del seminario Como, 4-5 novembre 1995 (s. 35-55). Como: Museocivicoarcheologico Giovio.

Wieland, G.

2002 Das Rätzel der Viereckschanzen. Archäologie in Deutschland, 6, 20-23.

Wiśniewski, Z.

1991 Średniowieczna technika budowy studni w świetle badań na nowym mieście we Wrocławiu przy ulicy Bernardyńskiej. Silesia Antiqua, 33-34, 106-139. 
Wolting, M.

2005 Motyw studni w literaturze i sztuce niemieckiej. Studium kulturoznawcze. Wrocław: Oficyna Wydawnicza ATUT, Wrocławskie Wydawnictwo Oświatowe.

Woźny, J.

1996 Symbolika wody w pradziejach Polski. Bydgoszcz: Wydawnictwo Uczelniane Wyższej Szkoły Pedagogicznej.

Vendtova, $\mathrm{V}$.

1966 Studne z doby vel'komoravskej v Pobedime. Slovenská Archeológia, 14, 417-438.

Zawisza, B.

1983 Konstrukcje studzienne z okresu wplywów rzymskich w Polsce [Maszynopis pracy magi-

Zielski, A., Krapiec, M.

sterskiej w archiwum Instytutu Archeologii Uniwersytetu Wrocławskiego].

2004 Dendrochronologia. Warszawa: Wydawnictwo Naukowe PWN.

\section{Źródła elektroniczne}

Juuti, P. S., Antoniou, G. P., Dragoni, W., El-Gohary, F., Feo, G. de, Katko, T. S., Rajala, R. P., Zheng X. Y., Drusiani, R., Angelakis, A. N.

2015 Short Global History of Fountains. Water, 7(5), 2314-2348; DOI: 10.3390/w7052314.

Pobrano z: http://www.mdpi.com/2073-4441/7/5/2314/htm

https://sjp.pwn.pl/szukaj/studnia.html

http://news.bbc.co.uk/2/hi/europe/8118318.stm

http://www.aggsbach.de/2011/09/water-in-the-paleo-and-neolithic/dostęp

Tegel, W., Elburg, R., Hakelberg, D., Stäuble, H., Büntgen, U.

2012 Early Neolithic Water Wells Reveal the World's Oldest Wood Architecture. PLoS ONE 7(12): e51374. DOI:10.1371/journal.pone.0051374. Pobrano z: https://journals.plos.org/ plosone/article?id=10.1371/journal.pone.0051374

\section{Źródla antyczne}

Pliniusz Starszy

1977 (Caius Plinius Secundus, Plinius Maior) Naturkunde, R. König, G. Winkler (red.), Zürich. Witruwiusz

1984 De architectura - Von der Baukunst, dt. Von C. Fensterbusch. Darmstadt: Olms Verlag.

\section{WELL - A SPECIAL OBJECT IN THE AREA OF THE ARCHAEOLOGICAL SITE. INTRODUCTION TO THE RESEARCH PROBLEM}

\section{S u m m a r y}

For years, these exceptional archaeological objects were not treated as a separate research problem, despite the fact that a significant increase in the materials resulting from the recent large area excavations provided numerous discoveries of wells. The titular features represent unique sources and they became an inspiration to take up the eponymous issue thanks to the discovery of 
over one hundred objects of this type at the site in Kwiatków, the vast majority of which are associated with the period of the Roman influence. Structures made of organic raw materials are highly rare in the space of a typical archaeological site, and wooden elements are extremely important sources of knowledge about a given settlement. They enable a dendrochronological research and a comparison of their findings with the dates obtained for the artefacts from the fills of wells and other features which are analogous in terms of chronology. The fills of these features can be analysed for the use of paleoenvironmental research. Unfortunately, the number of discovered settlements does not accord with the number of discovered wells, which is connected with the fact that the sites in question received only fragmentary study. Other restrictions on the objects of our interest result from the method of elaboration of the excavation results and their publication. The history of wells is truly compelling and the information about these features is found even in ancient sources. Early wells are associated with the establishment of the first stable settlements in the Neolithic period. With the times of the Przeworsk culture, wells gained in importance and more of them were dug in comparison with the earlier stages of prehistory. The basic criteria used for the classification of wells into individual types (known from the literature of the subject) include: the shapes of cribwork, the ways of their construction and the choice of raw material from which these structures were built. The wells occur together with a range of features related to the utilisation of the water intake and located in its immediate vicinity. These discoveries allow for extremely interesting interpretations of the functional connections between the individual complexes of this type. All kinds of ethnographic analogies prove extremely valuable sources, helpful in this type of analysis, which results from a low level of variability of the character of the structures in question over time. Functions of water wells are an issue inextricably linked to the location of these complexes in the settlement's space. The spatial development of the settlement and thus the choice of location for building a well was, undoubtedly, primarily motivated by pragmatism, but it could also reflect a certain vision of the image - structure of the world that its inhabitants possessed. Despite everything, potential ways of using this type of features is not so clear as it may seem. In the past, they fulfilled various functions, some of which could also be of special importance. A rich symbolism of water and, consequently, water wells themselves, suggest that these features could also play some roles in the rites present in the communities who were their users. This may be justified by the fact that water had a special significance for the prehistoric peoples. Wells mean far more in the space of the archaeological sites than just water intakes as, in fact, they are remarkably universal objects with a wide utilitarian potential as well as they create a significant symbolic zone. These are specific archives of time which enable the researchers to conduct many specialist analyses and to undertake interdisciplinary studies. Their uniqueness makes wells some of the most interesting objects of archaeological studies. 